\section{PLANNING AS A TOOL FOR MODERNIZATION IN TURKEY: THE CASE OF HERMANN JANSEN'S PLAN FOR MERSINN (1)}

\author{
Burak BEYHAN* ${ }^{*}$ Selçuk UĞUZ**
}

Received: 09.09.2011, Final Text: 27.04.2012

Keywords: early urban development plans and regulations; port cities; diffusion of planning ideas; Hermann Jansen; Mersin; Turkey.

1. This paper is based on the re-elaboration of the archive material collected and compiled by Burak Beyhan and Selçuk Uğuz in 2002. It also re-contextualizes some of the findings presented by them at the Colloquium named as "Mersin, the Mediterranean, and Modernity: Heritage of the Long Nineteenth Century".

\footnotetext{
* Department of City and Regional Planning, Mersin University, Mersin, TURKEY.

** İstanbul, TURKEY.
}

Early 20th century urban development plans and regulations as the culmination of the efforts made for the modernization of the cities constitute a special and substantive domain of focus for the historical analysis of cities in terms of understanding the nature and objectives of planning today. Yet, except for big cities such as Ankara, İstanbul, İzmir, Adana and Bursa, most of the cities in Turkey are not studied in depth within such a context. Unfortunately, those studies conducted for both big and small cities also do not properly explore the local socio-cultural and institutional atmosphere of the period, during which the respective plans were prepared. This paper partly fills these gaps by highlighting the inter-contextual and self-contextual characteristics of the planning efforts made for Mersin. Although the primary pursuit of this paper is to contextualize the planning efforts made for a mid-sized port city in the early 20th century in Turkey, it is also argued that a better understanding of urban transformation in Turkey during the respective period can be constructed through the illustrative case of Mersin that actually functions as a lens for the Turkish (port) cities which are not well-known. What is particularly evident from this historical inquiry is that Mersin reflects all the characteristics through which the leaders and intellectuals of the Republic of Turkey chose to modernize the cities in the country during the early years of the Republic.

\section{INTRODUCTION}

The aim of this paper is to highlight the early planning efforts made for Mersin, a port city located in the South of Turkey along the Mediterranean Coast. This task involves both the identification of the contexts within which Mersin can be properly located and the identification of Mersin itself as an independent context. In other words, it is argued that early planning efforts made in Mersin can be fully grasped only by employing a comparative perspective in relation to self-contextual and intercontextual elements of a city. Building on the network idea, this meso 
orientation leads us to consider space and individuals as active agents of the socio-economic life and at the same time to consider their formation in relation to socio-economic and technological forces. Thus, in terms of self-contextual and inter-contextual elements, units of analysis employed in this study range from the actors and events involved in the production of built environment and the first urban development plan of Mersin to the evolution of planning movements and regulations that were imperative in the formation of both the urban fabric of Mersin and the style of planning favored by Prof. Hermann Jansen who prepared the first urban development plan for the city during the 1930s.

Inter-contextual elements of Mersin can be considered at two different levels. The first level corresponds to the international context in terms of both diffusion of planning ideas, and the social, cultural and economic characteristics that can be attributed to a specific region covering parts of different countries bordering each other. In this study, the Eastern Mediterranean basin (Figure 1) corresponds to such kind of a specific region for the particular case of Mersin. Nevertheless, within the context of international diffusion of ideas globe itself actually constitutes the base for a proper inter-contextual analysis. Architectural historian Esra Akcan (2005: 72-151; 2009: 47-85) reveals the importance of inter-contextual elements particularly for the elaboration of the modernization of the countries historically receiving less academic attention than the Western world. For this purpose, on the one hand, Akcan (2005: 79-103; 2009: 47-61) traces the emergence of the garden city ideal in the UK and the 'translation' of the respective ideal from England to Germany at the beginning of the 20th century, which reveals the fact that garden city as a concept was transformed and resynthesized in the destination country (Germany) by inclusion of the existing conceptions for and expectations from the respective concept. On the

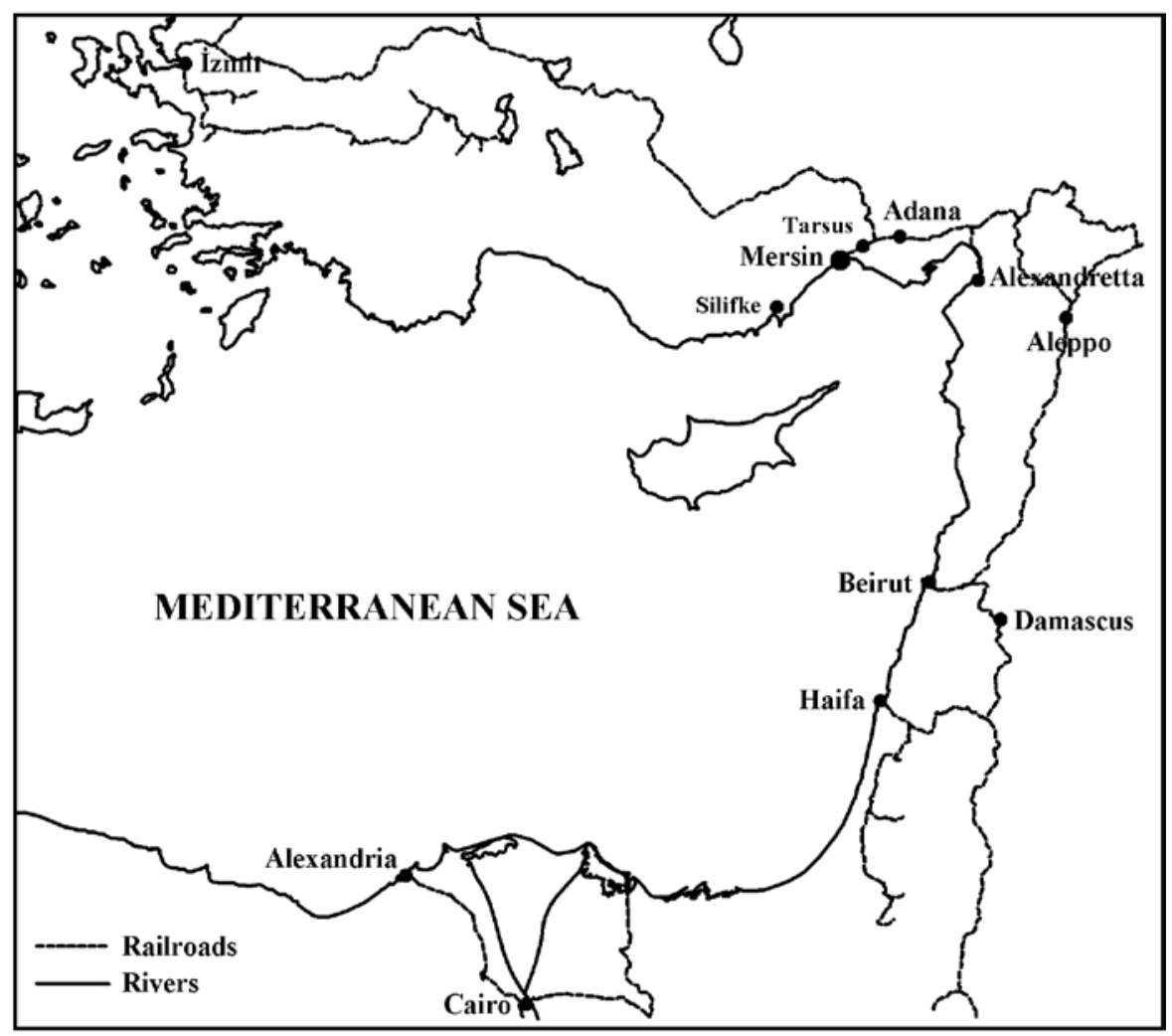


2. The reforms that were implemented in the Ottomon Empire beginning from 1839 in order to modernize society and state are known as 'Tanzimat'. These reforms heavily influenced the formation of the urban areas in the Empire. other hand, tracing the articulation of the ideals of Camillo Sitte with those of garden city model in Prof. Herman Jansen's urban development plans Akcan (2005: 108-151; 2009: 61-85) also unveals the translation of the garden city model from Germany to Turkey particularly through the hybridizations of the respective model with "the Turkish house discourse during the early Republican period in Turkey", first in the urban development plan prepared for Ankara and then briefly for the other cities in Turkey. Akcan's (2005; 2009) exploration of the details of cultural exchanges and evaluation of different experiences of the 'other' in relation to the diffusion of planning ideas is illustrative of the importance of the first level of inter-contextual elements revealing the merits of efforts made for the intertwined histories of modernization.

In this study, the second level for inter-contextual elements corresponds to the national context that shaped the general institutional and political framework for the development and planning of the cities in Turkey. In this respect, it should be emphasized that although during the last years of the Ottoman Empire there were some considerations for the modernization of cities according to the requirements of modern urban life, most of these efforts were made for mainly İstanbul and other big cities such as İzmir and Bursa. Owing to Tanzimat (also known as "the Ottoman Reform") initiated during the reign of Abdülmecit, spatial arrangements in other Ottoman cities were also subject to a series of rules aiming at the prevention of the problems experienced during the previous periods (2). However, one can not speak of a vast and all inclusive modernization movement for the last years of the Ottoman Empire, which does not only stem from the fact that during this period the Empire was engaged in a series of wars, but also originates from the conception of the problems attributed to the cities. It was only after the establishment of the Turkish Republic that the state devoted a great deal of attention and sources to modernization of cities in the country. In this respect, as Turkish urban planner and social-political scientist Çağatay Keskinok $(2010,173)$ remarks, urban planning experience in Turkey during the 1930s was based on the crucial social and economic policies of statism and populism that ranks among the basic principles of Kemalist ideology. Indeed, during the early years of the Republic, a series of modernization movements were underway; namely, construction of drinking water supply routes and distribution systems, sewerage systems, electricity provision and distribution systems, and modern communication systems. Urban plans as the culmination of these efforts, made for the modernization of cities can be considered as the final step of this process aiming at controlling the spatial development of cities.

Within the framework given above for the inter-contextual base of Mersin, the comparative dimension of the study is mainly based on the juxtaposition of Mersin with the overall framework, derived from the previous studies conducted for both other cities in Turkey (such as Ankara, Izmir, Adana, Bursa and İstanbul), and the evolution and international diffusion of planning ideas in a critical perspective. In the national context, architectural-planning historians such as İlhan Tekeli (1980, 1985), Gönül Tankut (1981, 1993), Zeynep Kezer (1998, 2010), Zeynep Çelik (1993), Ali Cengizkan (2002, 2004), Esra Akcan (2005, 2009), Hatice Ayataç (2007), Sinem Türkoğlu Önge (2007), Murat Gül (2009) and Duygu Kaçar (2010) and political scientists such as Fehmi Yavuz $(1952,1981)$, Ruşen Keleş and Bülent Duru (2008) tend to focus on İstanbul and Ankara as the main laboratories for the analysis of planning history in Turkey. However, some recent studies conducted by Turkish urban planner and planning historian 
Koray Özcan (2006) on the imprints of Tanzimat, architect and planning historian Cana Bilsel $(1996,2009)$ about planning of İzmir (Smyrna), another port city, and other planners and architects on other Anatoilan cities (such as the work by Duygu Saban Ökesli (2009) on Adana, and Bağbancı and Köprülü Bağbancı (2010) on Bursa) have revealed that the story is actually much more complicated, and that it necessitates a detailed investigation of the secondary cities in order to draw an accurate picture for the role and positions of cities in the evolution of urban planning experiences in Turkey. In a comprehensive study conducted by Keskinok (2010), it seems that there is an effort to balance the respective bias by focusing on the general national political framework, albeit Ankara is again prioritized over other cities because of its designation as the capital city of Turkey.

In fact, the particular case of planning efforts made for Mersin were first accounted for by Beyhan and Uğuz in 2002, at the Colloquium named as "Mersin, the Mediterranean, and Modernity: Heritage of the Long Nineteenth Century". This paper attempts to re-contextualize the planning efforts made for a mid-sized port city in the early 20th century in Turkey, employing a comparative perspective, but using the collected archival material compiled for the respective study, and elaborating on some of its findings. Although during recent years, several studies including Ünlü and Levent (2005), and Ünlü $(2007 ; 2009)$ were conducted in order to search for the influence of Prof. Hermann Jansen in the formation of the urban fabric of the city, they could not develop a proper framework for Mersin which draws importance on the evolution of relationships between self-contextual and inter-contextual characteristics of the city, in a systematic way. In terms of inter-contextual elements, these studies could not also properly comprehend the fact that in the construction of a more balanced story, port cities especially deserve serious consideration due to their potential as the productive fields of investigation for the articulation and international dissemination of planning ideas and movements.

Indeed, as being nodes of intersection of different modes of transportation, port cities are subject to not only a constant influx of people and goods, but also ideas and cultures (O'Flanagan, 2008, 4; Peerason, 1998, 60-1; McPherson, 2002, 77-8, 91; Kendall, 2002, 347). Based on this characteristic, in this paper it is argued that imprints of both the regulations introduced for the planning of cities and the planning ideas that emerged in the West and disseminated to other areas including Anatolia, can be best observed in the planning efforts made for port cities. It is no accident that the majority of cities for which an urban development plan was prepared in the period 1890-1939 by international practitioners analysed by the planning historian Stephen Ward (2005), were port cities except for the capital cities of the newly founded states. Indeed, it is observed that 20 out of 34 cities planned by an international planner mentioned by Ward are actually port cities.

Although port cities are generally peripheral places compared with the capital cities that are mostly centrally located in terms of both their geographical location and the size of their relationship with other cities, they flourish more within international relations owing their strategic position in the network of cities (Hein, 2011a, 15). Actually this is completely in line with the conceptualization of 'strength of weak ties' developed by the eminent American socio-economists Mark Granovetter (1973) and 'structural holes' formulated by the American sociologist Ronald Burt (1992)(3). Indeed, compared with the more isolated parts of the
3. Burt (1992) argues that economic actors embedded in structural holes can easily gain access to critical information required to be competitive. Granovetter also considers 'weak ties' as information-rich channels of knowledge flow. 
network of cities, port cities actually have a set of diversified channels to the rest of the network by means of maritime transport, but these channels are not as voluminous as the ones established by the capitals and some of the inland cities occupying, graph theoretically, the most degree central positions in the network in terms of their connection to rest of the network.

Within the context drawn above, Mersin can be considered as a perfect laboratory for the contextualization of both the planning efforts made for a Turkish city, that is neither old nor a new capital, and also international dissemination of planning ideas. The articulation of Mersin's individual story into the contexts of the emergence of a planning discipline, the evolution of Turkish urban structure and the dissemination of planning ideas, provides us with important notions that are currently missing in the literature. In this respect, focusing on the distinctive and transformative characteristics of Mersin, the central quest of this study is to reveal the extent to which the first urban development plan prepared for the city and the story revolving around the preparation of the respective plan are imprinted with the planning regulations, social, economic and political conditions, and particularly the dominant planning movements of the time.

The first urban development plan for Mersin was prepared by Prof. Hermann Jansen, famous German architect and urban planner. Jansen had studied architecture at Technical University of Aachen and in the early years of his career he had worked under Camillo Sitte (Reuther, 1974, 341; Kezer, 1998, 18). After receiving the degree of Dr. Engineer in 1919 from Technical University of Stuttgart, he was appointed as professor of town planning at Technical University of Berlin (Reuther, 1974). He was especially famous for his award winning urban development plans prepared for Berlin (1910), Madrid (1929), and Ankara (1932) (Wynn, 1984, 124-7; Ward, 2005, 124-5; Schenk and Bromley, 2003, 129; Neuman and Gavinha, 2005, 992-5). Jansen also worked in Norway, Bulgaria and Latvia, and prepared urban development plans for Dresden, Leipzig, and many other cities in Germany, as well as Prague, Budapest, Bratislava, Burgas and Philippoupolis in Central and Eastern Europe, and Montevideo (Ward, 2005, 124-5; Hastaoglou-Martinidis, 2011, 181). Being influenced by the developments both in Europe and the US, the principal characteristics of his plans are the extensive use of urban greenbelts associated with an open space system and the importance assigned to both protection of historical heritage and healthy environment for the residents.

Although Ward $(2005,124)$ argues that Jansen was involved in the preparation of urban development plans for other Turkish towns before he was engaged in the planning activities for the capital city, it is known that Jansen was invited to Turkey particularly to prepare the urban development plan for Ankara and before that he did not prepare any urban development plan for other Turkish cities (4). It is important to notice that Jansen's invitation to Turkey actually developed contingently after the

4. Ward (2005) refers to Keleş and Payne (1984) in order to argue that Jansen "had already worked on other Turkish towns before" he was requested to prepare the urban development plan for Ankara, capital city of Ankara. Yet, no where in Keleş and Payne (1984) there is such kind of an information or implication. The fact that Keleş and Payne (1984) give figures for and mentions about the urban development plan again prepared by Jansen for Gaziantep before the case of the capital city might have led to a confusion for Ward. visit of a Turkish delegation from the municipality (Şehramaneti) of Ankara to Berlin in 1927 in order to establish some contacts for the preparation of an urban development plan for Ankara (Yavuz, 1980, 5; Cengizkan, 2004; 35-6, 104). Although they first contacted Ludwig Hoffmann, an eminent professor of architecture and planning, he kindly declined the request of the committee to prepare the urban development plan for Ankara by arguing that he was 75 and he could not make longer journeys (Cengizkan, 2004, 35, 104; Şahin, 2007, 44). Nevertheless, he suggested Prof. Hermann Jansen and Prof. Joseph Brix, 'co-winner of the Greater Berlin planning 
5. The first prize given for the Greater Berlin competition 1908 was divided between two proposals; one submitted by Hermann Jansen and the other one submitted by Joseph Brix and Felix Genzmer (Town Planning Review, 1910, 169)

6. See Steiniger and Bocher (2009), and Beyhan, et al. (2010) for comparsions of different FOSS for GIS.

7. Use of the term modernity in this paper refers to its conventional use in terms of the socio-spatial processes triggered by the rise of industrialization in the Western world during the 19th century. competition held in 1910' (5), for the respective task. After agreeing with Brix and Jansen, the committee returned to Turkey and decided to open an invitation led international planning competition adding also Léon Jaussely, famous French architect and planner trained at the well-known Ecole des Beaux Arts, to the list of competitors (Cengizkan, 2004: 35-6, 104; Şahin, 2007: 44; Tekeli, 1980, 58). Mersin's planning story began after Jansen arrived in Turkey where he also planned many other Turkish cities including not only Mersin, but also other cities located in both Çukurova (Cilicia) region (Tarsus, Adana and Ceyhan) and other parts of Turkey (Gaziantep and İzmit).

In this study, elaboration of the planning efforts made for Mersin is mainly based on the analysis of the local newspapers (particularly Yeni Mersin) published in Mersin especially during the second half of the 1930s that witnessed the preparation of the first urban development plan for the city. Overall, the study reveals that as sources of historical knowledge, local newspapers are very valuable for urban history in general, and for planning history in particular. This seems to be especially true for the period and the area under investigation. Indeed, although the archival records for Ankara, serving as the capital of Turkey officially since 1923, and İstanbul, which had served as the capital of the Ottoman Empire, are more accessible and available compared with those for other cities, for relatively small cities, it is much more difficult to obtain the archieve records required for the analysis of the historical evolution of the planning efforts.

Another important attempt of the paper is the employment of Geographic Information Systems (GIS) in the analysis of the spatial documents obtained for the study. Although the large part of the story behind both the urban development plan of Mersin and its preparation is sketched with reference to the local newspapers, other published materials were also employed in combination with the local newspapers. As a matter of fact, the quality of the cartographic materials given in the local newspapers was very low. Apart from the original plan that was obtained from the Center of Urban Studies for Mediterranean (Akdeniz Kent Araştırmaları Merkezi - AKKENT) at Mersin University, majority of the cartographic material were redrawn from the books of Şinasi Develi, a lawyer and famous local historian in Mersin. All the maps employed in the paper have been georeferenced and rectified by employing the oppourtinies provided by Free and Open Source Software (FOSS) for GIS (especially gvSIG (6)), which greatly facilitated the elaboration of the urban development plan by overlapping it with the other cartographic materials available to this study.

Departing from the introductory framework drawn above, this paper firstly attempts to draw the inter-contextual framework for the formation and diffusion of planning ideas with particular reference to adoption of the respective ideas by Prof. Hermann Jansen who prepared the first urban development plan for Mersin. Subsequently, with an attempt to identify the institutional and cultural context within which the imprints of 'modernity' (7) on an Eastern Mediterranean port city can be properly studied and exposed, evolution of the planning efforts and regulations in the Ottoman Empire and Turkish Republic is analyzed as an integral part of the modernization process experienced in Turkish cities, and in connection with Western experience and influence. This is followed by the identification of the imprints of planning regulations on the spatial structure of Mersin and the analysis of the urban development plan prepared by Prof. Hermann Jansen for the city. What is evident from this undertaking is that Mersin is 
8. For a short review of park movement see Olmsted (1914, 177-8). The American landscape architect Frederick Law Olmsted's study is also illustrative of the transatlantic exchange of planning ideas and practice in terms of European influence on the US during the early $20^{\text {th }}$ century.

9. The integration of park movement into the 'City Beautiful' movement through the idea of application of a deliberate design by the artist-planner searching for a geometrical and pleasing arrangement to provide the surroundings of daily life with beauty can easily be followed in Olmsted's (1914) analysis of the evolution of the town planning movement in the US.

10. The public health historians Simon Szreter and Graham Mooney (1998) reveal that during the 19th century the life expectancy at birth was very low for majority of the industrial cities in British towns because of the unhealthy conditions in the respective cities that were rapidly growing at that time. As example of this, life expectancy in Manchester and Liverpool "was only around 30 or 31 years in both the 1850s and 1860s" (Szreter and Mooney, 1998, 88-9).

11. However, it is known that two years before Howard, Theodor Fritsch, "published a book entitled Die Stadt der Zukunft with the subtitle Gartenstadt in the second 1912 edition - The city of the future (Garden City)" (Schubert, 2004: 3; Batchelor, 1969: 197). In this edition, Fritsch claims that his book published in 1896 is "the true foundation of today's garden city". very illustrative of the characteristics of the way through which the leaders and intellectuals of the Republic of Turkey chose to modernize the cities in Turkey, especially in the early years of the new Republic.

\section{THE GENESIS AND EVOLUTION OF PLANNING MOVEMENTS AND CONCEPTS FAVORED BY JANSEN}

As is particularly evident from F. Tillyard's (1913) review of the evolution of the regulations in relation to the town development in the UK during the 19th century and R.E. Willcocks' (1911) review of town planning legislation in several European countries at the beginning of the 20th century, it can be argued that modern city planning firstly emerged in the form of regulations and as an attempt to solve the problems associated with the industrial development experienced in Europe during the 18th and 19th centuries. In his review of town planning legislation in Great Britain, Germany, New Zealand, and Sweden at the beginning of the 20th century, Willcocks (1911, 211) notes that the main intention in the respective legislative measures was "to safeguard the inhabitants of towns from living in overcrowded, sunless, and unhealthy areas" caused by rapid industrialization. The idea behind the 'park movement' (8) that can be considered as one of the most influential movement in the planning history of the USA in terms of its collaboration with and integration into the City Beautiful movement was also imprinted with similar kinds of considerations (9). Indeed, as the American lawyer Andrew Crawford $(1910,75)$ notes at the beginning of the 20th century, the system of parks can not be considered only as a reflection of the City Beautiful, but also as a necessity of the City Healthful and the City Convenient.

Prior and parallel to these pragmatic and reformist efforts made for the spatial reorganization of (industrial) cities, a series of utopian approaches (such as Robert Owen, Charles Fourier and Saint-Simon) have been developed for the planning of cities during the 18th and 19th centuries (Batchelor, 1969; Tekeli, 1980). By drawing on the general considerations devoted by More to the organization of towns in a country, the urban design historian Peter Batchelor $(1969,185)$ reveals the similarities between the studies realized by Robert Owen, Charles Fourier, Saint-Simon, Jeremy Bentham, Claude-Nicholas Ledoux, and Pemberton during the subsequents centuries and More's Utopia. As planning historian and social-regional scientist Tekeli $(1980,10)$ notes, utopian approaches and pragmaticreformist efforts were actually not independent from each other and they can be considered as the products of the socialist movement questioning the standards of living in the industrial cities of the 18th and 19th centuries. Indeed, while the first city planning experiences in the Western world can be considered as a pragmatic-reformist attempt to solve the problems associated with the industrial development experienced in Europe and the USA during the 18th and 19th centuries, in the background they were actually products of urban utopians deeply rooted in the socialist policies as a reaction to improve health conditions negatively affected by the industrialization process (10).

According to Cherry $(1969,49)$, taken together with the utopian approaches and the public health problems caused by the rapid industrialization these concerns were especially crystallized in Ebenezer Howard's (1902) 'Garden Cities of To-morrow' that gave "a new direction as a particular solution for the problems created by urban growth" (11). Garden city can be considered as a synthesis built upon the experience by early utopians 
12. As Tekeli (1980) remarks, Jansen was already known to be a planner embracing the planning principles of Camille Sitte and he published his award winning plan in the magazine Städtebau founded by Sitte in 1904

13. Duempelmann (2009: 158) notes that Hermann Jansen requested "Wacker's Manual of the Plan of Chicago, an educational publication issued by the Chicago Plan Commission in 1911". and utopian socialists (Cherry, 1969, 52-3; Batchelor, 1969; Buder, 1969, 391). Indeed, Howard's (1902) Garden City ("the town-country magnet") as a satellite solution reflects a search for not only an ideal physical environment, but also the social idealism of utopia by blending urban and rural through strong consideration devoted to the self-sufficiency. By considering his plans prepared for the cities in Turkey, in turn Tekeli (1980) argues that Jansen was greatly influenced by both the Garden City movement and Camillo Sitte whom he had worked under as it is remaked in the introduction (12). Compared with Howard, Camillo Sitte puts main emphasis on the artistic principles in city planning. In his influential book titled Der Städtebau nach seinen künstlerischen Grundsätzen (City Planning According to Artistic Principles) and published in 1889, Camillo Sitte (2006) strongly criticized the planning operations characterized by broad, straight boulevards and public squares arranged mainly according to the needs of traffic. According to Sitte (2006, 229-42), the design objectives of the medieval cities that shaped the streets and buildings in the urban fabric of the respective cities should be followed in city planning. Accordingly, instead of regular grid-iron pattern Sitte actively favored irregular street alignments and T-intersections that reduce the number of possible conflicts among streams of moving traffic.

As it will be discussed in the fourth section, as a reflection of the influence of Camillo Sitte and the Garden City movement, Jansen, on the one hand, explicitly searches for the strategies to preserve the old city form, and on the other, tries to limit the size of cities and to prevent the pitfalls of over-urbanization by exploiting the opportunities provided by the rural areas. In this respect, in line with the garden city models of Howard, Jansen divides the residential parcels by large green axes, and in line with the principles of Camillo Sitte, he identifies and preserves the historical buildings by designating them as important nodes of pedestrian circulation through curving streets that create a constantly changing vista and elements of surprise. Although by taking into account the parallels given above not only Tekeli (1980), but also Ünlü and Levent (2005), Akcan (2005, 2009), Mumcu Uçar and Özsoy (2006), Ünlü (2007), Saban Ökesli (2009), Cengizkan (2010) and Kaçar (2010) associate Jansen with Camillo Sitte and the Garden City movements, German landscape architect Sonja Duempelmann $(2009,158)$ successfully reveals that there are also interconnections between the pionners of the City Beautiful movement and Jansen (13). By focusing on the greenbelts proposed by Jansen in his plan prepared for the Greater Berlin, Duempelmann (2009, 158-9) also draw parallels between Jansen and "German countess and suffragette Adelheid Dohna-Poninska, who in 1874 had already argued for extensive greenbelts to alleviate the social ills in big cities".

Another particular concept with which Jansen's style of planning has strong affinities is Stadtlandschaft (urban landscape). Analysis of the history of the concept of Stadtlandschaft reveals that parallel to Germanic Heimatculture it actually refers to a harmony and give-and-take relationship between urban structures and natural environment (landscape) (Sohn, 2003: 133; Mantziaras, 2003, 157). In this particular context, the term was actually first used in the scientific geography by a group of German geographers including Max Eckert and Siegfried Passarge (Mantziaras, 2002, 24). Although during the 1920s it was first Max Eckert who extensively used the term in his studies, 'Stadtlandschaft' appeared in the title of a book first in a study conducted by Siegfried Passarge in 1930 (Mantziaras, 2003, 157). In the conceptualization of Stadtlandschaft where the build environment and 
14. Indeed, the Garden City model drawing on the opportunities provided by the rural areas (such as self-sufficiency) and aiming at the creation of a healthy community is actually intrinsically connected to Stadtlandschaft relying on "the rural cooperative movement and the movement for Heimat-protection". Nevertheless, as German architect Elke Sohn (2003: 130) points out, the Garden City as a concept combining urban structures and natural environment has always been more widely known than Stadtlandschaft. nature combine in a harmonious manner, the town is not conceived as an entity separate from its surroundings (Mantziaras, 2002, 24; Sohn, 2003, 133). Although the employment of the concept in architecture and planning with particular reference to the term itself can be first observed in the studies of the German architect and city planner Hans Bernhard Reichow and the German architect Rudolf Schwarz as early as the early 1930s, in terms of "the reduction of the problems associated with urban density by dividing the city into smaller units surrounded by green areas" (Hein, 2006, 77) the earlier implementation and promotion of the respective concept can easily be traced back to those urban planners especially influenced by the Garden City movement (14).

Stadtlandschaft has some parallels not only with Garden City movement, but also with the planning principles of Camillo Sitte in terms of its search for a harmony between the subentities in an urban landscape. For example, Rudolf Schwarz's Stadtlandschaft as exemplified in Cologne was "a low density urban environment, with human constructions and nature merging together in a discontinuous, clustered and ordered manner, integrating historical cores, new residential zones, industry and landscape into a unified system structured by the transportation networks" (Mantziaras, 2002, 15). A similar kind of approach can also be identified for Jansen beginning from his earlier works including his famous Berlin plan prepared in 1910. Indeed, already by 1910, as the German urban design historian Wolfgang Sonne $(2003,222)$ notes, Hermann Jansen actually formulated the creation of 'urban landscapes' as the ultimate aim of urban design in his project submitted to the planning competition held for the Greater Berlin. In terms of translation of the garden city ideal from England to Germany and articulation of the respective concept with the ideals of Camillo Sitte by Herman Jansen, Akcan (2005, 115; 2009: 65) remarks that harmony and unity of urban environment was a desired and unavoidable attribute for the proponents of both Camillo Sitte and Garden City models in Germany. Owing to the conceptualization of the city as an organic living entity that is both autonomously active and regulated, in Stadtlandschaft urban functions can be designed and ordered according to their own laws in order to let them grow and correspond harmoniously (Sohn, 2007, 516).

The most surprising aspect of Stadtlandschaft is, perhaps, the employment of the concept by opposite political camps as an ideal for urban planning. Oscillating between the nationalist-racist ideas and the internationalsocialist ideas, Stadtlandschaft has been a continuous and favorable concept particularly in the history of German urban planning (Sonne, 2004, 294; Sohn, 2003, 121). Indeed, as the German geographer Tilman Schenk and the British geographer Ray Bromley $(2003,121)$ argue, Stadtlandschaft was actively used by Gottfried Feder, one of the early key members of the Nazi party, in order to present "a vision of new cities integrated with the natural environment". In Gottfried Feder's designs, the strips of open space is employed to separate neighborhoods and the size of urban settlements is limited to 20,000 inhabitants in order to allow the formation of new cities in rural areas and guarantee the presence of a green belt (Mantziaras, 2002, 30; Schenk and Bromley, 2003, 121). It is interesting to note that the leading planning professor at Technical University of Berlin was Hermann Jansen while Feder was also instructing there. 


\section{PLANNING EFFORTS AND REGULATIONS IN CITIES OF THE OTTOMAN EMPIRE AND THE REPUBLIC OF TURKEY, IN CONNECTION WITH WESTERN EXPERIENCE}

Having outlining the genesis and evolution of the planning movements and concepts that had either influenced or been promoted by Hermann Jansen, as a second step, the institutional context of the planning activities in the cities of both the Ottoman Empire and the Republic of Turkey can be sketched by drawing on the similarities and differences between the Western and the Ottoman-Turkish contexts untill the end of the 1930s: As it is discussed in the previous section, the basic and practical rationale behind the emergence of planning practice in the West was to prevent the health problems caused by the rise of industrial activities in European and American cities though they were actually the products of the socialist movements triggered by the idealism of Renaissance and democracy. It was a reaction against the problems created by industrialization. Consequently, in the early years, the first planning practices were inevitably bound with the legislation and measures taken for the prevention of epidemics in cities (such as the construction of proper sewerage systems).

It is notable that the first regulations related to planning practice in the Ottoman Empire coincided with these developments experienced in Europe and in the USA. Nevertheless, the basic thrusts behind these regulations were different from their Western counterparts. The basic thrusts behind the Ottoman case were the followings; (1) the prevention of 'big fires' (15) that could damage the cities, (2) the enlargement of roads so as to make new means of urban transportation possible, and (3) the construction of new residential districts around the cities in order to house the increasing urban population (during the 19th century, the population in Anatolia increased rapidly due to the migration of people from the areas previously dominated by the Ottoman Empire to Anatolia) (Tekeli, 1980, 33-4; Tekeli, 1985, 882-4; Aktüre, 1985, 896-8; Özcan, 2006, 158). Although some of the problems

15. One of the most important factors that facilitated the reorganization of urban structure in the Ottoman cities had been the big fires of the 19th century. Wooden houses of the old cities were very vulnerable to fires. Thus, new houses started to be built of stone or brick.

16. There are some controversies on timing of the first legislation in the Ottoman Empire regarding the production of the built environment: On the one hand, Yerasimos (1999: 7) argues that the first regulations concerning the formation of urban areas in the Ottomon Empire can be dated back to 1539, which proves that the lack of order in urban environment stems from the failure to implement these regulations. On the other hand, Gül and Lamb (2004: 424) argue that, parallel to the reforms in other areas, building codes "began to be issued in by the Ottoman administration" as early as 1796. In spite of this dispute on the issue, as Yerasimos argues, the regulations introduced by the reforms known as Tanzimat (such as 'Ebniye Nizamnamesi') prevented the lack of authority in the implementation of the respective regulations. Another important characteristic of the regulations introduced in 1848 is the elimination of the conflict between the basic principles of Tanzimat and Tanzimat Ilmühaberi in which the Islamic laws ordering the determination of the heights of the buildings according to the religious and ethnic identities prevailed (Özcan, 2006, 158). leading to the earlier urban planning regulations in the Ottoman Empire were also imperative in some European countries and especially Nordic ones (see for example Sundman (1991), Lorange and Myhre (1991), Larsson and Thomassen (1991), Hall (1991) and Hein (2011b)), compared with the Western world, what was almost absent in the Ottoman context was the foundation of a strong base for industrial production.

Although towards the end of the Ottoman era and during the early years of the Republican period, there were some production units operating in capitalist sense, artisanal form of production was still dominant in most of the cities in Anatolia. Thus, in contrast to the Western context, one can not establish a direct connection between the industrialization and the earlier planning experiences in the Ottoman cities. It is observed that all the measures introduced by the building certifications issued in 1939 after Tanzimat Declaration were mainly directed towards the prevention of the big fires that occurred in İstanbul (Özcan, 2006, 158). The first planning legislation of the Ottoman Empire, the Buildings Regulations (Ebniye Nizamnamesi), was subsequently published in 1848 (16). This law introduced strict regulations about the expropriation of urban lands, building permissions, construction of buildings, width of roads, and height of the buildings on the major streets (Tekeli, 1980, 37-8; Tekeli, 1985, 885). While the basic worry of the Buildings Regulations was not to modify the physical appearance of the city but to prevent the problems created by the fires, it should also be noted that, as Tekeli $(1985,885)$ argues, the basic principle 
17. Indeed, as urban planner and historian Zorica Nedović-Budić and architect-planner Branko Cavrić (2006: 405) remark, already by the end of the 18th and the beginning of the 19th centuries, the Balkans was an active arena for national movements leading to "the struggle for independence from the Ottomans, Italians and Austro-Hungarians". According to Nedović-Budić and Cavrić (2006), respective period also witnessed the first serious initiatives directed towards the creation of a formal system of planning in the Balkans. A similar line of argumentation can also be observed in Conley (2010). Nevertheless, the eminent architect, city planner and historian Stéphane Yerasimos (1999) notes that in contrast to North Africa and the Balkans that began to disintegrate from the Empire during the 19th century, İstanbul and other Turkish cities have less narrow and organic streets, which actually owes to the modernization movements triggered by the regulations of Tanzimat.

18. In a speech delivered by Tekeli (2005) one year before Özcan (2006) it is argued that the new regulations were first implemented in the plan prepared again by Luigi Storari for Aksaray fire place in İstanbul. During the same period, another plot plan was prepared for Bursa by Suphi Bey, an engineer, after an earthquake in the city in 1855 . Respective plan that was compiled and published in 1861 was prepared to be used in the reconstruction of the city (Pinon, 2006, 537). of Tanzimat, equality between the nations, was also crystallized in these regulations.

The height of buildings would no longer be determined according to ethnic identity of the owner of the respective buildings but rather according to the width of the road along which they were placed. Introduction of these regulations was actually a response to the tendency of the fragmentation of the Empire during the 19th century. As Serbian architectural historian Tanja Conley and architectural-urban historian Emily Makaš $(2010,2)$ note, in terms of incorporation of "the forces of modernity into their political and socio-cultural structures" both the Habsburg and Ottoman Empires developed some strategies in response to the emergence of nationalism that accelerated the disintegration of the respective Empires in the Central and Southeastern Europe. In this challenge experienced during the mid-nineteenth century although the Habsburgs were more successful in addressing the problems associated with rapid urban growth and industrialization by searching "for increased efficiency and the beautification of the urban fabric", in the Ottoman Empire the reforms known as Tanzimat addressing "some of these urban issues along with political and social structures" were not very successful owing to the fact that it was "too late, as it paralleled the fragmentation of the empire and failed to reassure and solidify its population" (Conley and Makaš, 2010, 2) (17).

Apart from the question regarding the success of Tanzimat in prevention of the disintegration of the Ottoman Empire in terms of incorporation of the aspects of modernity into the political and socio-cultural structure of the Empire, in Turkish literature, it is usually argued that all the practices and regulations introduced for the planning of İstanbul were later generalized to the rest of the cities located in the Empire. Although this is a generalization based on the introduction and implementation of the first planning regulations in the Ottoman Empire, it is well documented that the first formal attempt for the implementation of the new regulations was experienced in İzmir after a big fire in the city. Özcan $(2006,162)$ argues that the plans prepared by Luigi Storari, an Italian engineer and planner, for the Armenian neighbourhood Basmane in 1848 after the fire, and the overall road network plan for the entire city in 1854 can be considered as the first planning experiences initiated within the legal framework introduced by Tanzimat regulations (18). As Özcan and Turkish urban designers Uğur Bozkurt and Hatice Ayataç note, the plans prepared by Storari successfully exhibit the grid-iron pattern which is one of the most characteristic imprints of the planning regulations introduced by Tanzimat reforms into the Ottoman cities (Bozkurt, 2004, 123; Özcan, 2006, 163; Ayataç, 2007, 118).

After a big fire in İstanbul in 1864, the Buildings Regulations dated 1848 were phased out and the Roads and Buildings Regulations (Turuk ve Ebniye Nizamnamesi) was put into place. This set of regulations was more detailed than the previous one. Being applied not only to İstanbul, but also to all the other cities in the Ottoman Empire, the Roads and Buildings Regulations introduced measures and rules about the preparation of cartographic maps, expropriation of urban lands, parceling of lands, widths of roads and height of buildings (Tekeli, 1980, 41; 1985, 886). The first spatial outcomes of the respective regulations were the creation of new neighborhoods designed for the resettlement of the people migrating from the Balkans and Crimea (Özcan, 2006: 164-5). One can easily distinguish the respective 
neighborhoods from rest of the city because of the regular grid pattern of the roads dictated by the law in these new neighborhoods. While the particular districts of the cities accommodating mainly immigrants or re-planned after the big fires exhibit a regular grid pattern, as Özcan $(2006,179)$ argues, the existence of "Sultan izni" over even the regulations introduced after Tanzimat signals the trend to sustain the traditional and pre-Tanzimat forms of production of built environment in the Ottoman cities.

The efforts to shape urban environment in the Empire according to the requirements of the modern world continued with the Buildings Act (Ebniye Kanunu) that was put into effect in 1882. In many respects, the Buildings Act was the first proper urban planning law of the Ottoman Empire (Tekeli, 1980; Özcan, 2006). With the introduction of this law, which was far more detailed compared with the previous legislations, the Roads and Buildings Regulations were phased out. According to this law, the municipality was responsible for the preparation and declaration of the cartographic maps of the roads and the urban areas destroyed by big fires. The respective law necessitated the organization of the road system in a hierarchical way and the redevelopment of the fire places through reparcellation (Aksoylu, 2003). In this respect, the Buildings Act also brought some new rules in relation to the creation of new built-up areas for settlement (Aksoylu, 2003; Özcan, 2006, 171). Accordingly, the construction of new residential districts would be allowed only if those willing to take such a responsibility donated a piece of their land to the municipality for the construction of the public buildings (such as schools or police stations) (Özcan, 2006, 171). It is noticeable that the law compelled the landowners to surrender " $25 \%$ of their lands for the public spaces and roads" (Konursay, 2004, 109).

According to the Buildings Act dated 1882, those willing to construct new residential areas would also contribute to the construction of pavements and sewerage system. As Tekeli $(1985,887)$ notes, these rules show that the state became aware of the fact the speculative pressures upon the development of cities were increasing the burden on the state. Nevertheless, the respective law was overlapping with the Vilayet Act put into effect in 1864 and partly regulating the issues related with the water supply and construction of roads. In the subsequent years, great achivement were realized in the preparation of the modern cartographic maps of the Empire. In this respect, the first serious attempt was made in Eskişehir by army officers Hakkı Efendi and Şevki Efendi with the support of the Cartography Commission (Taksim-i Arazi Komisyonu) and French experts in 1894 (Özcan, 2000, 9). In 1911 with the initiatives of Brigadier Şevki Bey, the Ministry of Defence initiated the preparation of cartographic maps of the Empire at various scales (1/200,000, 1/50,000 and 1/25,000). Subsequently, cartographic maps of the various regions were completed in 1921.

The last regulations that also bear upon on Jansen's Mersin Plan is the Buildings and Roads Act (Yapr ve Yollar Kanunu) that put into place in 1933. Respective law prohibited the formation of dead-ended (cul-de-sac) streets in the cities and set the minimum width of the street as 9.50 meters. It is important to notice that the minimum value set for the width of the street in the law was low compared with the Western standards of even early 19th century. For example, in Birmingham when the Commissioners obtained some "power of street widening" in 1801, they set the width of new streets as 14 yards (12.8 meters) (Tillyard, 1913, 550). Similar kinds of 
measures can also be observed in other countries. For example in Nordic countries beginning from the first half of the $19^{\text {th }}$ century onwards the width of the roads increased and a regular grid-iron plan emerged in the cities. After a big fire in Turku in 1827, a new plan was prepared for the town. In the respective plan, in constrast to the irregular organic structure of the old town, the new street network "was laid out on a rigorously rectangular basis" and the "streets were generally $18 \mathrm{~m}$ wide", except for three streets that were $24 \mathrm{~m}$ wide (Sundman, 1991, 75).

In spite of its major deficiencies, the Buildings and Roads Act was operational until the Law 6785 of 1956 (Settlement Act / Imar Kanunu) was put into force. To what extent all these regulations and legislations were operational (or implemented) and determined the development of the cities in Anatolia is a major question. As it is discussed above, some implementations of these legislations are visible in certain parts of the cities (such as the grid-iron pattern of the immigrant districts and the areas reconstructed after big fires) (Aktüre, 1978 and 1985; Tekeli, 1980; Tekeli, 1985; Bozkurt, 2004; Özcan, 2006; Ayataç, 2007). Indeed, the emergence of regular grid-iron patterns in the Ottoman cities can be directly linked to these regulations and legislations, which sharply contrast with the organic pattern of the old cities. In the next section of this paper delving into the planning efforts made for Mersin, it is possible to observe both imprints of these regulations and the planning ideas that emerged in the West and disseminated to the other areas including Anatolia.

\section{IMPRINTS OF PLANNING REGULATIONS ON MERSIN AND THE URBAN DEVELOPMENT PLAN PREPARED BY HERMANN JANSEN IN CONNECTION WITH OTHER EARLIER PLANNING ATTEMPTS IN TURKEY}

Since Mersin had already developed along the regulations introduced throughout the 19th century for the minimization of the problems experienced in the previous periods (such as the big fires, the accommodation of new urban populations, and the narrow and dead-end streets which were not suitable for modern modes of transportation), it had well planned and regular streets exhibiting somewhat of a grid-iron pattern (19)(Figure 2). This grid-iron pattern in Mersin can easily be observed in some of the old districts of the city (such as Mesudiye, Mahmudiye and Cami Şerif ). However, after the establishment of the Republic, the rigidness of the grid-iron pattern dictated by the planning regulations introduced during the 19th century was challenged by a number of foreing urban planners who had been invited to the country in order to plan the cities according to the needs of the modern world.

It is particularly important to notice that except for Antakya (Antioch) and İskenderun (Alexandretta), almost all the cities (Adana, Mersin, Tarsus and Ceyhan) in Çukurova were planned by Jansen. Although they are not available today, it is known that earlier urban development plans for Antakya (1932) and İskenderun (1932) were prepared by René Danger (Fries, 1994; Açıkgöz, 2008)(20). The fact that René Danger was also involved in the planning of İzmir led us to think that the preference of local governments in Çukurova partly reflected the antipathy fuelled by the invasion of the region by France during the First World War. In spite of these local, particular and possible objections to certain figures due to their affiliation with a national idendity, it can be easily argued that Turkey was an active arena for the international diffusion of planning ideas facilitated not only to the natural growth but also to the migrations from the areas previously dominated by the Ottoman Empire.

20. Danger was also active in the planning of cities such as Aleppo (1931), Tripoli (1931), Beirut (1934), Damascus (1935) that were under French mandate during the period between 1920 and 1946 (Harb, 2003, 72; Açıkgöz, 2008; Vacher, 2002, 50). 
Figure 2. Map of Mersin prepared by Hikmet Serdengeçti in 1937. Source: Reproduced by employing gvSIG from Jansen plan.(This is a tentative map of Mersin; as some existing land-use patterns were very difficult to read from the original plan, only the most legible part of the existing land-use could be redrawn.)

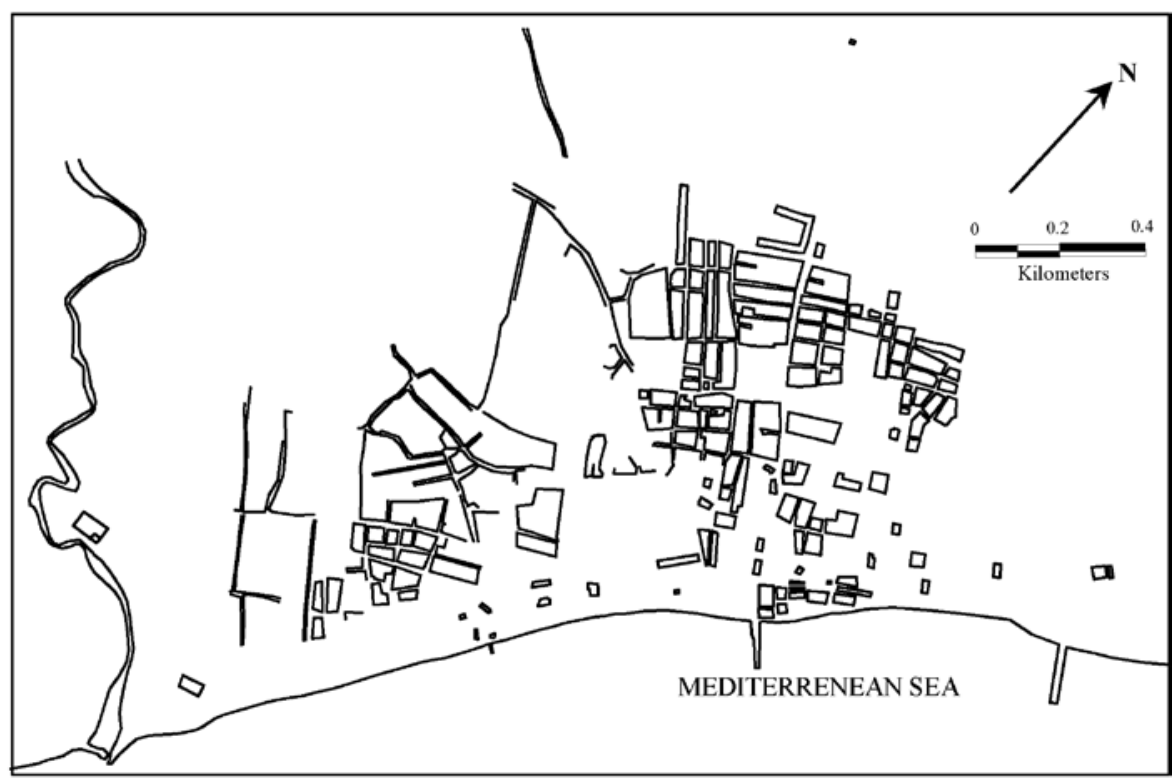

by the international networks of technocrats and bureaucrats. As noted above those foreing urban planners invited to Turkey were instrumental in questioning the rigidness of the grid-iron pattern dictated by the planning regulations introduced during the 19th century.

Indeed, a new wave of urban planning was initiated with the practice and intellectual contribution of the foreign planners in the country (Yerasimos, 1988). This wave was actually a local counterpart of the Republican reforms initiated at the national level in accordance with the principles of Kemalist ideology and it was accompanied by a proliferation of discourses on urbanism in Turkey (Yerasimos, 1988, 115). The Journal of Municipalities (Belediyeler Dergisi), the first issue of which appeared in June 1935, devoted a section each month to the questions on 'Urbanism'. Agache, Danger and Jansen contributed to the journal. Linked with the ideas elaborated in the journal, it is noteworthy that these foreign planners (including Jansen) particularly influenced by Camillo Sitte and the Garden City movement tried to create a symbiosis between the old and the new, and also between the urban and the rural. They were not, of course, against modern urban life but rather the way through which it was introduced to the cities.

Overall, in Turkey Haussmann type planning that crudely ignored the old city had not been very influential. Nevertheless, it was possible to see some ideological formations and planning practices supporting Camillo Sitte and the Garden City movement (Tekeli, 1980, 35; Ozcan, 2006, 168-9). This was not chiefly because of the landownership structure and the general resistance of residents of the city, but to a certain extent due to the scarcity of the financial resources and especially the resistance from the associations responsible for the conservation of the historical buildings. Indeed, it can be argued that the lack of financial resources required for huge construction works is one of the important factors preventing the adoption of a strict Haussmann type planning in the Ottoman Empire. Muhafaza-i Asari-Atika Cemiyeti, the Ottoman association established for the conservation of the buildings and artifacts with historical and cultural heritage, was also firmly contesting the destruction of the old part of the cities whenever a new project 
21. Parallel to those factors preventing the adoption of a Haussmannian planning, those Ottoman officials missing the old glory days of the Empire and against to the Westernization of the country were particularly ready to accept a style of planning favoring the preservation of old city form instead of destroying it (Tekeli, 1980, 35). Although during the period between 1879 and 1882 some kind of a Haussmannian planning can be observed for Bursa during the governorship of the city by Ahmet Vefik Paşa, who served as the ambassador of the Ottoman Empire in Paris and had the chance of observing the great changes introduced by Baron Haussmann into the city during his stay in the city in 1860, it is observed that the plan introduced by Ahmet Vefik Pasha did not crudely destroy the historical and cultural fabric of the city (Özcan, 2006, 169; Bağbancı and Köprülü Bağbancı, 2010, 1124).

22. The new Buildings and Roads Act put into place in 1933 privileged the geometric order over the organic order of old cities, which was very contradictory with the planning movements and concepts favored by Jansen for whom strict regulations introduced by the respective law (as an extension of earlier legislations) were not acceptable from the point of view of Camillo Sitte's urban design principles in which organic patterns of old cities are preserved and, in an appropriate way, extended to the newly planned urban areas.

23. In the case of Ankara, land speculations were interrupting the implementation of the plan prepared by Jansen (Yavuz, 1980: 6; Akın, 2007, 162-4). Jansen was aware of the fact that the urban plans prepared by him could only be successfully implemented if the necessary precautions were taken in order to prevent the speculations over the urban land (Yavuz, 1980, 6). Even as Kaçar $(2010,53)$ notes, it is related that "[i]n a conversation with Mustafa Kemal, Jansen asked if he had the power and ability of implementing the plan". Indeed, although the central government officials provided the planners with all the opportunities to prepare the plans for the cities in Turkey, they could not prevent the speculations over the urban land. Because of the speculations, the plan prepared for Ankara could not be successfully implemented. After a number of changes introduced to the plan in accordance with the demands of powerful interest groups, Jansen would say that "you can remove my sign from the plans prepared for Ankara" (tr. by the author) (Yavuz, 1980, 6). Consequently, in 1938, he "resigned from all of his work in Ankara" (Kaçar, 2010, 54). destroying the old buildings was initiated particularly in İstanbul (Tekeli, 1980, 34, 48)(21).

During the early years of the Republican period, the bourgeoisie who were not against the modernization of the country in accordance with the standards of the life available in the Western world were again more receptive to a style of planning that favors the preservation of cultural and historical artefacts thanks to their desire to modernize the country by employing not only their own capital, but also their own cultural setting and values that are reflected in the historical urban fabric. Camillo Sitte's style of planning was more acceptable for the respective social group rejecting the life style of the Levants and still searching for the modernization of the country and her cities (Tekeli, 1980, 35). The cadre who established the Turkish Republic also favored the adoption of a style of planning that tried to balance not only old and new, but also urban and rural. As Tekeli (1980) argues, this actually owes very much to the fact that the leaders and intellectuals of the Republic wanted to realize the modernization of the cities through their own methods and not through a strictly Western way. In fact, the basic purpose of the plans prepared during these early years (1933-1945) was to modernize the existing spatial structure of the Anatolian cities according to the needs of industrial society, not to enlarge them.

What had been experienced in Mersin was completely in line with these considerations devoted to the modernization of the cities in Turkey. After his arrival in Turkey, as remarked in the introduction, Prof. Hermann Jansen prepared an urban development plan for not only Ankara (1932), but also for Mersin (1938), Tarsus (1940), Adana (1940), Ceyhan (1939), Gaziantep (1938) and İzmit (1938) (Cuda, 1939; Tekeli, 1980: 78; Develi, 2000, 8-9; Saban Ökesli, 2010). It is widely acknowledged that Jansen was particularly influenced by both Camillo Sitte and the Garden City movement. As discussed above in length, he was also one of the earliest and most successful promoters of the concept of Stadtlandschaft (urban landscape). When his Mersin plan is analyzed together with speeches delivered by him on various occasions as published in the local newspapers, it becomes evident that it is strongly imprinted not only with the principles of Camillo Sitte and the Garden City movement, but also with an active promotion of the concept of Stadtlandschaft. But it should be emphasized that new regulations put into effect by the new Republic were not very different from the earlier ones, and they created difficulties for planners in sustaining their internal coherence in relation to the planning movement which they favored (22). In addition to this, the decisions taken by public authorities before the planners were given the responsibility of preparing the plans together with the activities of powerful interest groups further prevented the crystallization of their own style of planning. This was especially true for Jansen when he prepared the urban development plan for Ankara (23).

Though it seems that in the case of Mersin, additional restrictions on Jansen were few, it can be argued that there is some counter evidence for this. For example, in 1938 (on the 23rd of May), when Atatürk visited Mersin, he pointed to the north of the city with his walking stick and told the Mayor of Mersin: "I requested you to open five wide streets towards the north. Why did not you begin the construction of these roads?", and in response to his reply, he said: "There can be no excuse for this. These streets should be opened. They should be especially oriented from the south to the north. The settlement should be shifted towards the north of the city." 
24. 'Sehircilik Mütehassisi', Yeni Mersin, 3 October 1936, 2.

25. See for a good polemic on these issues, of which Jansen was part, New Mersin: 'Yansenin Mektubu Herhalde Yolunu Şaşırdı', Yeni Mersin, 10 October 1936, 1-2; 'Yansen Tezini Müdafaa Ediyor', Yeni Mersin, 7 October 1936, 1-2; 'Yansen Gözüyle Mersin', Yeni Mersin, 8 October 1936, 1-2. The respective story develops around the speech of Jansen which was published in Yeni Mersin and involved some implicit criticisms directed by Jansen towards the operations and performances of the Mersin municipality in relation to the construction of the port and public works. See also 'Mersin Şehri Umumi İmar Planını İzah Eden Rapor', Yeni Mersin, 23 February 1938, 2.

26. See 'Profesör Yansen Söylüyor', Yeni Mersin, 14 May 1937, 2.

27. 'İçme Suyu', Yeni Mersin, 8 June 1938, 1.

28. Although the formal records for the respective hotel, the hotel Ziya Paşa, are available as early as 1900 in the AOCs (Annuaire Oriental du Commerce), in the accounts of the Ottoman traveller Karçınzade Süleyman Şükrü, there is some kind of evidence about the existence of this hotel, or at least its building as early as 1886 (Beyhan, 2009, 204). While he was going to his place of mission, in 1886 Karçınzade made a journey from İstanbul to Antalya through Isparta and Ağlasun, and came to Mersin via a ship under the Greek flag from Antalya. According to Karçınzade, in Mersin, there were recently erected big and modern buildings constructed by Ziya Paşa during his governorship of Adana, and used as hotels and casinos in the city, his first stop in Cilicia (Mert, 1999).

29. One day, in Tarsus, Jansen saw that the centuries old tree he visited each time when he arrived had been cut down, which extremely hurt his feelings. Upon this event, in an interview to Yeni Mersin, he emphasized that these kinds of trees could be used to attract tourists to the region. 'Profesör Yansen Söylüyor', Yeni Mersin, 14 May 1937, 2.

30. 'Profesör Yansen Söylüyor', Yeni Mersin, 14 May 1937, 2.

31. As Soffer and Stern (1986) reveal, in port cities old and new centers continuously overlap with each other.

32. 'Yansen', Yeni Mersin, 9 April 1935, 1; 'Belediye Bütçesi 319.000 Lira', Yeni Mersin, 12 May 1935, 1; 'Mersin Planı Bu Yil Yapılacak', Yeni Mersin, 16 July 1935, 1; 'Şehirlerin İmarı İçin Yeni Kararlar', Yeni Mersin, 21 April $1938,1$.
(Aykın, 2007, 118) (tr. by the author) Considering the fact that in the urban development plan for Mersin prepared by Jansen, there were actually six wide and green pedestrian axes running in the north-south direction, at first glance, the remarks given above can be interpreted as an intervention to the plan. Nevertheless, when it is considered that Atatürk probably saw the plan prepared for the city, one can easily infer that the leader of the Republic actually questioned the implementation of the plan in accordance with the proposals made by Jansen. Indeed, as explained below in detail, development of the city was directed towards the north and a number of wide and green pedestrian axes were proposed from the north to the south. The only question remains with regard to the term, 'road', in the anecdote. Most probably, the main intention was to question the implementation of the pedestrian axes.

Furhermore, most of the time, in the case of urgent construction works, Jansen was requested to provide the overall framework within which these could be realized. For example, before the completion of the urban plan, Jansen was requested to prepare a detailed plan of the area covering the garden of the municipality, the Republic Square and the statue of Atatürk (24). However, in the case of decisions related to the port, things were much more spontaneous, out of control of the planner as generalized for port cities located in the Eastern Mediterranean basin (Soffer and Stern, 1986). But Jansen was sensitive to these issues (25). For example, when he saw the construction work aimed for enlargement of docks in the Mersin port, he grew angry as he was not willing to let Mersin grow into a big city (26). This particular reaction by Jansen also reflects his strong commitment to the principles of both Camillo Sitte and the Garden City, for which Howard defined a population limit of maximum of 32,000 inhabitants as an ideal. In 1940 the population of Mersin was already 30,007 reaching 36,463 in 1950 (Beyhan, 2009, 208).

What follows from the newspapers is that, at the end, Jansen succeeded in stopping the enlargement of the custom dock. On June 6, 1938, the Assembly of Mersin municipality held an extraordinary meeting (27). In this meeting, the decision taken to enlarge the customs docks was cancelled in accordance with the decisions taken in the plan prepared by Jansen because large stores and entrepots in the plan were placed in a separate district. As a result, the decision to demolish the post-office in order to gain some space for the enlargement of customs docks was also given up. The Assembly decided to use the post-office owned by the municipality as office space. Today the building which is one of the oldest in Mersin, known to be used as a hotel from 1900 to 1937 (28), is still used by the Mersin branch office of the General Directorate of Post and Telegraph Organization (PTT), and certainly owes its survival to Jansen's efforts.

In accordance with his alignment with the Garden City movement, Jansen was against actions disturbing the characteristics of small cities (29). According to Jansen, neither the historical and natural characteristics of small cities nor the design of their buildings should be ignored (30). Very consistent with his style of planning was the imprint of the basic characteristics of the Garden City movement (limiting the size of the cities equipped with large green axes), the Camillo Sitte ecole (respect to the old), and the Stadtlandschaft approach (a low density urban environment characterized by a harmony not only between urban fabric and nature, but also between historical urban core and new residential and industrial zones proposed in the plan through a unified system structured by the transportation networks). In fact, 
33. 'Mersin Planı Bu Yıl Yapılacak', Yeni Mersin, 16 July 1935, 1.

34. Formal procedures required by the Ministry of Interior Affairs for preparation of urban plans and construction of infrastructure systems were so numerous that an active division of works was realized between the Mayors of Tarsus and Mersin in order to tackle them. For the preparation of urban plans, Jansen needed to have a license given by the Ministry of Interior Affairs and the responsibility to deal with these kinds of procedures was assigned to Mithat Toroğlu, the Mayor of Mersin. 'Uraylar Kongresinde Neler Görüşüldü', Yeni Mersin, 6 November 1935, 2.

35. In 1930s, especially during the period of the plan preparation, Jansen was very popular in local media. He was closely followed by local newspapers (especially Yeni Mersin). Headings from newspapers are very illustrative: 'Jansen will supervise urban development plans of all cities in Turkey' ('Profesör Yansen Angaje Ediliyor', Yeni Mersin, 5 October 1935, 1); 'Jansen is in İzmir' ('Profesör Yansen İzmirde', Yeni Mersin, 27 October 1936, 2); 'Jansen completed the urban plan of Adana' ('Adananın İmar Planı', Yeni Mersin, 26 December 1937, 2).

36. 'Profesör Yansen Şehircilik Uzmanı Sehrimize Geldi', Yeni Mersin, 27 November 1935, 1; 'Profesör Yansen', Yeni Mersin, 28 November 1935, 2.

37. 'Şehirlerin İmarı İçin', Yeni Mersin, 30 January 1936, 1; 'Bilit Mersin Belediye Reisliğinden', Yeni Mersin, 3 March 1936, 3; 'Şehir Haritasını Mühendis Hikmet Serdengeçti Yapacak', Yeni Mersin, 24 March 1936, 1.

38. 'Şehir Haritasını Mühendis Hikmet Serdengeçti Yapacak', Yeni Mersin, 24 March 1936, 1.

39. 'Şehircilik Mütehassisi', Yeni Mersin, 3 October 1936, 2; 'Yansen Gözüyle Mersin', Yeni Mersin, 8 October 1936, 1-2.

40. 'Belediye Meclisinde H. Yansenin Gönderdiği Şehir Planı Görüşüldü', Yeni Mersin, 11 February 1938, 1.

41. 'Mersin Şehri Umumi İmar Planını İzah Eden Rapor', Yeni Mersin, 23 February 1938, 2; on the consecutive days of 24-28 February, 2 .

42. 'Müstakbel İmar Planı Dahiliye

Vekaletince Tasdik Edilmiştir', Yeni Mersin, 10 March 1939, 1

43. The respective law required that urban plans should differentiate land use according to three different uses: industrial, commercial and residential. In addition, a 50 year-projection was to be maintained for urban population, and the amount of lands allocated to different uses had be determined, according to the needs of the projected population (Tekeli, 1980, 69). the characteristics of port cities seem to be more appropriate for a kind of planning that tends to sustain the importance of the old center and protect the historical heritage of the city (31). Thus Jansen should have experienced less difficulty with the plan of Mersin, than other cities for which he prepared plans. Indeed, what is evident from newspapers is that the kinds of problems that he experienced in Mersin were mostly of a technical nature, and not directly related to the restrictions imposed on his style of planning. In other words, his plan was never questioned by local officials in terms of its integrity sustained by the planning principles he favored and promoted. Rather, he was usually requested to provide technical assistance for the solution of problems encountered during the plan implementation.

When taken overall, preparation of urban development plan for Mersin was a lengthy process involving many problems such as delays caused by decisions taken in Ankara, and the delay in preparation of the cartographic map of the city. Although after the invitation of Turhan Cemal Beriker, the Mayor of Adana, Jansen came to Çukurova and agreed to prepare the urban development plans of Adana, Tarsus, and Mersin, and even the first installment to him for the preparation of the urban development plan of Mersin was allocated in the 1935 budget of the Mersin municipality, he could not begin to prepare the plan immediately because a law that was put in effect just after the agreement with him, that for cities of population over 10,000 people, approval of a commission headed by the Minister of Interior Affairs, with experts from other ministries, was now necessary (32). Consequently, the Mayors of Mersin and Tarsus visited Ankara in order to request permission of the Minister for preparation of urban plans and construction of water supply and distribution systems in Mersin and Tarsus (33). The Minister allowed them to proceed, but the completion of formal procedures took a few months (34). What is evident from the news published in Yeni Mersin in relation to initiatives of the mayors of Mersin, Tarsus and Adana is that in contrast to the argument of Saban Ökesli (2010,4), Mersin, Tarsus, and Adana were not particularly selected by Turkish Government to be planned by Jansen, albeit the government assigned a significant importance to the respective cities due to their critical location in Çukurova Region, "the largest and most fertile agricultural land in Turkey".

In November 1935, Jansen visited Mersin in order to explore the city (35). He made some investigations around the Bahçeler District, the secondary streets, the Müftü Bridge and the Hospital Street, and took some notes on the map (36). Since the cartographic map of the city was not complete, he could not finish his analysis. Consequently, in order to make the preparation of the plan possible, on 17 March 1936, completion of the missing parts of the cartographic map of Mersin was tendered to Hikmet Serdengeçti, a well-known engineer in the city (37). Hikmet Serdengeçti should have prepared the map within four months (38). But what is evident from the interviews held with Jansen is that cartographic mapping of the city was still incomplete in October 1936 when he returned to Mersin (39).

Because of similar delays, Jansen could finish the plan in the beginning of 1938: in February 1938, the plan prepared by Jansen was studied by the Assembly of Mersin Municipality and a commission was established in order to analyze the plan in a detailed context (40). After the analysis of the commission, a report that explains the plan was published in Yeni Mersin (41). One year later, in March 1939, the plan was approved by the Ministry of Interior Affairs (42). According to the plan, in accordance with the new Buildings and Roads Act (43), the city was to be composed of three parts: (1) an 


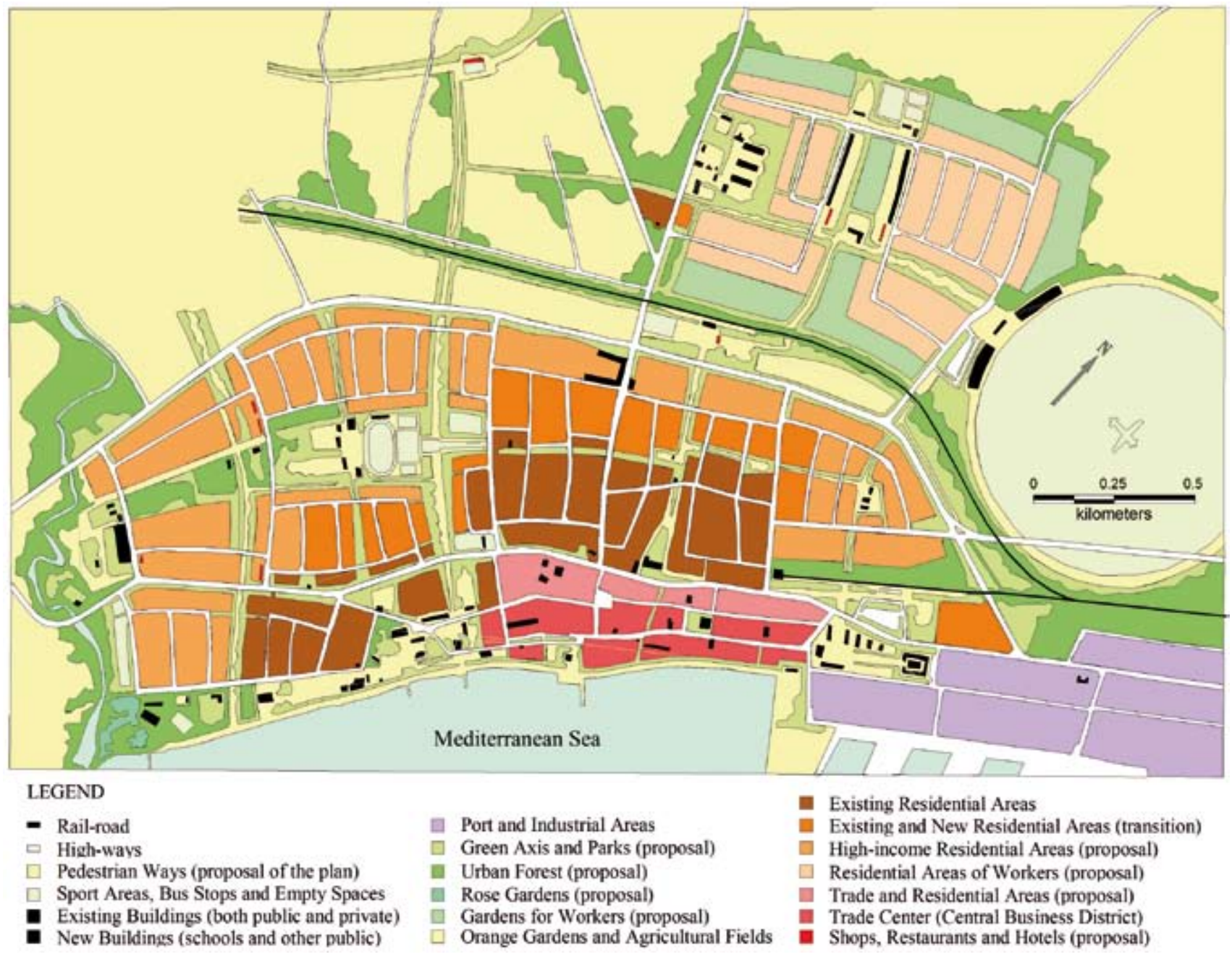

Figure 3. The urban development plan prepared by Jansen for Mersin in 1938 (The copy of the original plan prepared by Jansen was obtained from AKKENT and reproduced by employing gvSIG for this study. As some existing and proposed land-use patterns were difficult to read from the original plan, to overcome the difficulties experienced in the determination of the exact (both existing and proposed) land-use of some areas, 'plan notes' published in Yeni Mersin greatly contributed the reproduction of the drawing. Interviews with Sinasi Develi and the map of Mersin produced by French cartographers in 1920 also provided the paper with the basis to decide the boundaries of the existing city in the 1930s.)

Figure 4. Superimposition of the map showing the generalized land-use proposed by Jansen on the green axes proposed by him for Mersin.

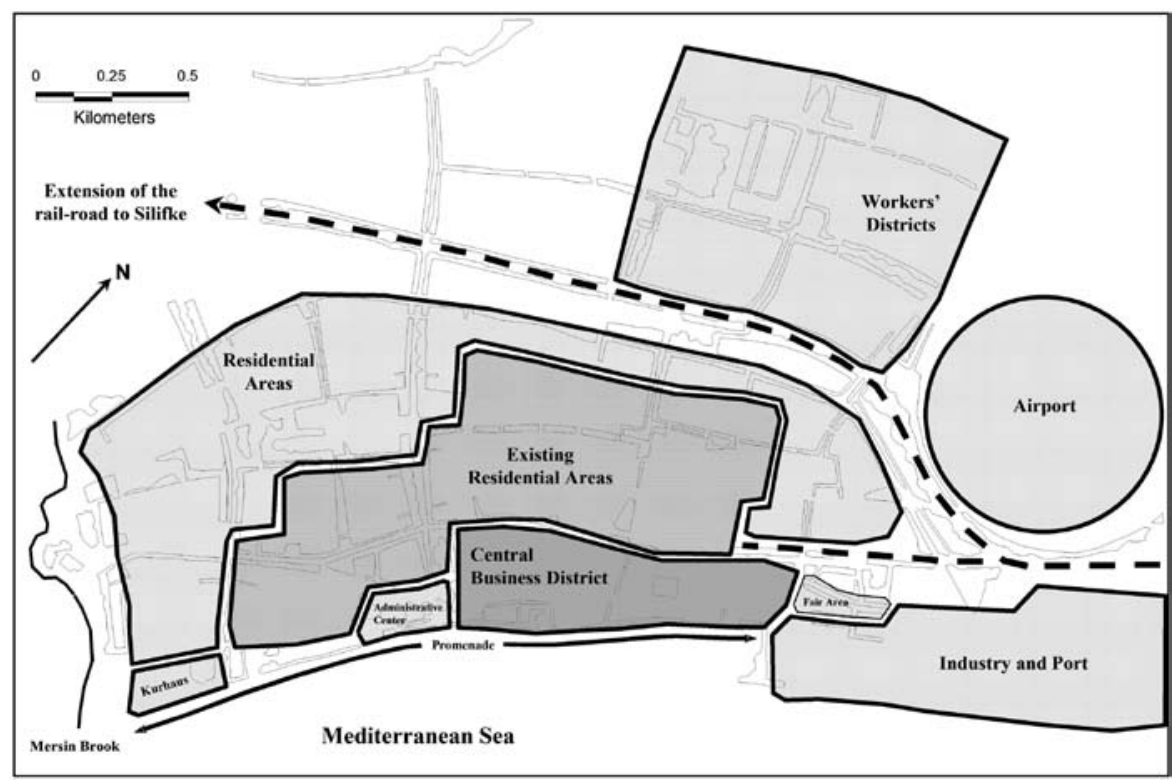


44. 'Müstakbel İmar Planı Dahiliye Vekaletince Tasdik Edilmiştir', Yeni Mersin, 10 March 1939, 1. Also Develi (2000)
Industrial District, (2) a Central Business District (CBD) and (3) Residential Districts (Figure 3,4)(44). When the general schema proposed is analysed in comparision with Jansen's other plans, one can easily identify certain parallels between Mersin plan and the ones both in Europe and Turkey. Especially in Turkey Jansen employed a template for all the cities he planned in the country. According to this template, as noted above for Mersin, the city is divided into certain zones defined for industrial, residential and CBD uses (Cuda, 1939; Yavuz, 1981; Türkoğlu Önge, 2007; Saban Ökesli, 2009; Keskinok, 2010). As a prerequisite of the Garden City movement and in line with the concept of Stadtlandschaft, respective zones were always separated from each other by wide green axes and interconnected to each other by a hierarchical and regular road network. Concurrent to this was the consideration devoted to the protection of historical urban fabric in compliance with the principles of Camillo Sitte and again Stadtlandschaft's emphasis on the harmony between not only built environment and nature, but also old and new urban fabric.

In his famous plans prepared for the capital cities of Germany, Spain and Turkey, Jansen always employed a framework, which is imprinted with the basic characteristics of not only Garden City movement and Camillo Sitte, but also particularly Stadtlandschaft. In both Berlin and Madrid, Jansen proposed greenbelts surrounding the city centers (Wynn, 1984, 125; Kaçar, 2010, 46). Especially the radial green corridors proposed by Jansen for the Greater Berlin in order to connect the inner and outer rings consisting of forests, parks, gardens, and meadows can also be observed in the urban development plan prepared by him for Mersin, albeit, as it is revealed in the following part of this section, in a much more different fashion which is more appropriate for a seaport city. Radiocentric decentralizing model used by Jansen in his Madrid plan in order to enclose the central urban core surrounded by a green zone is again illustrative of his affinity with Garden City model of Ebenezer Howard (Wynn, 1984, 125). In Ankara in line with the principles of Camillo Sitte, he preserved the picturesque old town around the citadel and proposed the development of the new government buildings in the southern direction. Dividing the city into functionally specialized zones separated from each other by wide green belts and also interconnected by a regular street network, he proposed lowdensity residential areas around the town, which exposes his alignment with Garden City movement, and his promotion of the concept of Stadtlandschaft.

Turning back to outlining the proposals made by Jansen in his Mersin plan and searching for the imprints of the planning movements and concepts with which Jansen's style of planning have clear affinities, firstly it is observed that in the plan in industrial and central business districts, except for the cellar, the maximum number of floors would be three. The maximum height of cellars would be two meters and the maximum height of the other floors would be four meters. In residential districts, again except for the cellar, there would be a maximum of two floors. The height of cellars would not exceed two meters and the height of the other floors would not exceed four meters. This low-density urban environment was a result of the Garden City movement and the concept of urban landscape.

The industrial district, also covering the port facilities, would lie between the railway station (for cargo), the sea and the fair grounds to the east of the city. Old industrial units producing noise and pollution would be relocated to and agglomerated in this industrial district placed outside the city. 


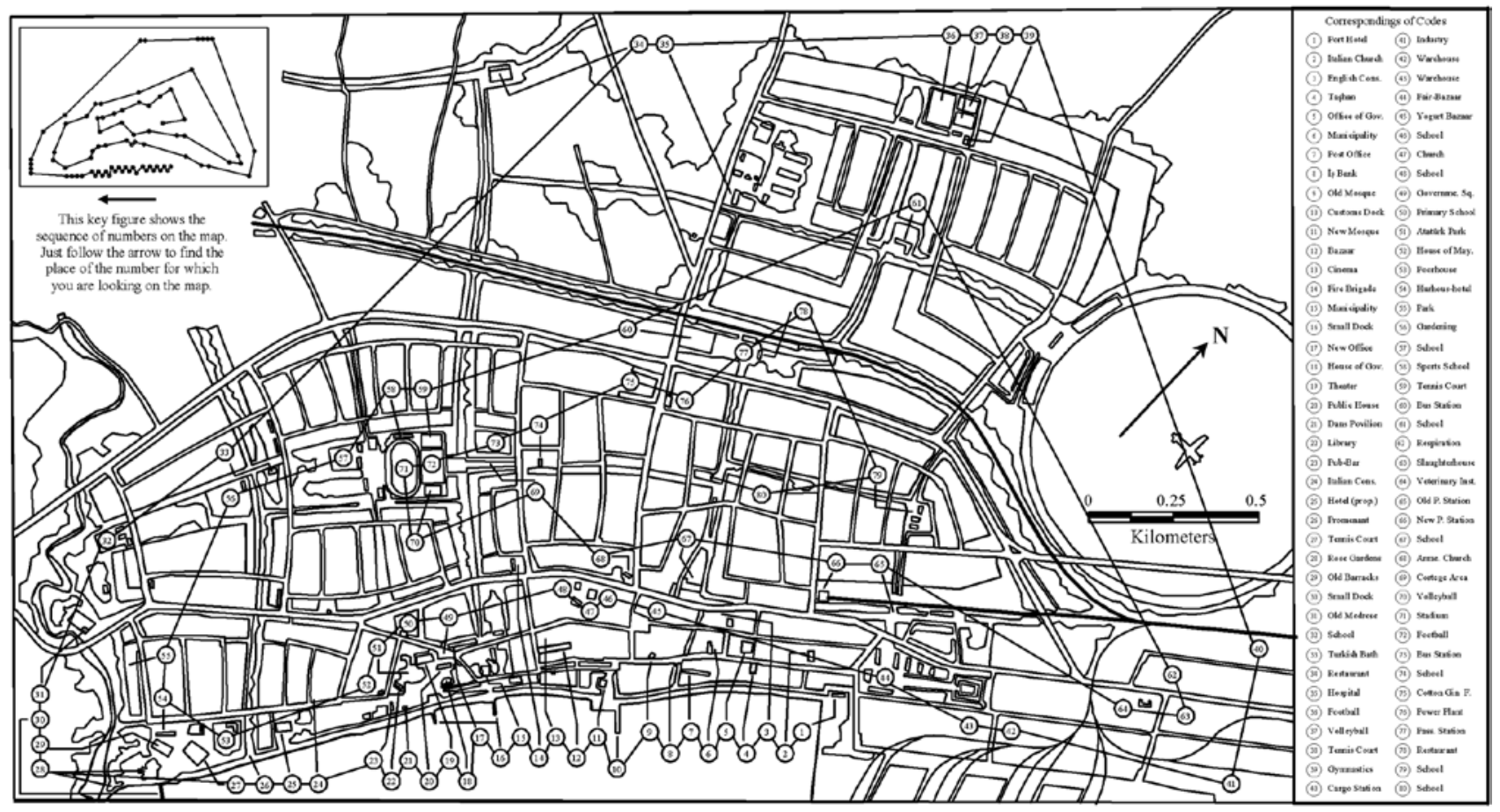

Figure 5. Important places and buildings identified in the urban development plan prepared by Jansen in 1938 .
All the existing industrial plants would be located along the road going to Tarsus at the east of the city because, as Alfred Cuda $(1939,45)$, one of the two assistants helping Jansen for the production of urban designs in Turkey, notes, the interconnections between the railway, highway and the port were well arranged there. The existence of harbor facilities in close proximity to the proposed industrial district was also another supporting factor. The preference of the eastern end of the city for the industrial activities was also in line with the the prevailing winds in Mersin. As 'the

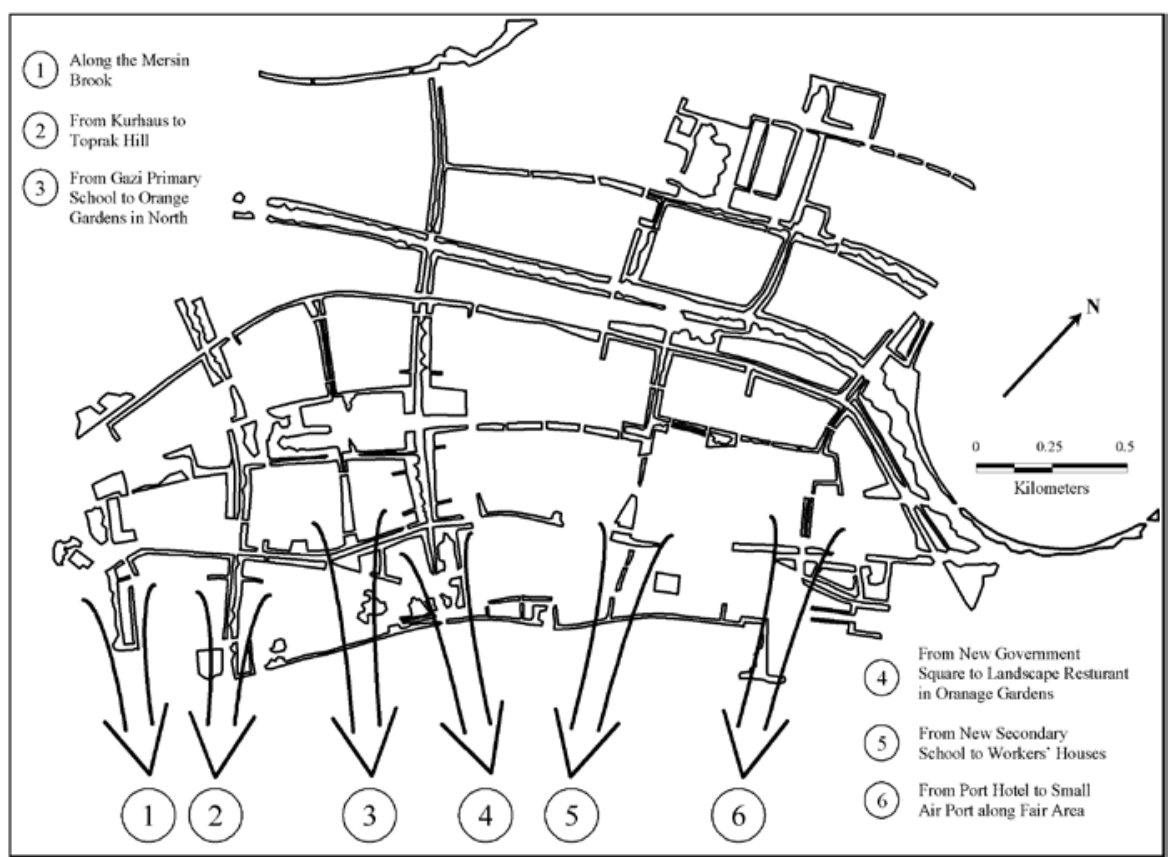

Figure 6. The green axes proposed by Jansen for Mersin. 
prevailing winds in Mersin blow from west to east' (Özsoy and Örnektekin, $2008,24)$, it is observed that Jansen placed all industry, port and the train station to the east of the city center, while recreational areas, beach facilities and sports stadiums were mainly located to the west of the center.

The CBD would lie between the industrial district and the public cinema (Kurum Cinema; Çocuk Esirgeme Kurumu), from the fair grounds to the 'new administrative center' of the city, upon the already existing commercial center. The residential areas would lie beyond these districts towards the north and west of the city till the Mersin brook. As Develi $(2000,124)$ notes, Jansen's plan, except for the residential district designed for workers, mainly covered the old residential districts of the city.

However, as it has been noted above, in Turkey the basic thrust behind the urban development plans prepared between 1933 and 1945 was just to modernize Anatolian cities and not to enlarge them. Further, the style of planning favored by Jansen was against the creation of larger units of settlements and rather commending the creation of a system of settlements in which the maximum population that an individual settlement may have is restricted to a certain number of people.

If the plan and the report that explains it are further analyzed together with the interviews held with Jansen, the imprints of particularly Camillo Sitte and the Garden City movement can easily be identified in the plan. In this context, the first concern should be devoted to the identification of the extent to which the plan explicitly tried to preserve both the historic buildings and the old urban pattern, and even tried to extend the old into the new residential and commercial areas that would be introduced by the plan. This harmony between old and new, also urban and rural can further be considered as a reflection of Jansen's search for an urban landscape in Mersin. What is evident from both the plan and the other documents related to it is that in the plan not only each historical building was carefully identified in the city (Figure 5), but also that, via the report, it was explicitly proposed that the respective buildings should be protected in accordance with the laws. Concurrent to this were the proposals developed for the old and new segments of the city. For the old city, Jansen suggested that redundant roads should be closed to vehicular traffic and allocated to the inhabitants residing along them as small gardens to plant trees, which would change the landscape of the city.

In addition to this, he recommended that roads should not necessarily be regular. They should be planned in such a way that those traveling along them could see the beauties of the city. In this way, as he noted, one could also economize on expropriation costs. It is important to note that these concerns on the design of the roads prevent the domination of the urban fabric by a strict grid pattern. This is particularly important as a conscious challenge to the grid-iron urban pattern dictated by the regulations of that time in Turkey. Camillo Sitte's T-intersections can also be easily observed as the main form of intersection for the roads proposed in the plan (Figure 3). Furthermore, allocation of the redundant roads to the residences as small gardens can be considered as a reflection of the self-sufficiency favored by not only Garden City movement, but also Stadtlandschaft. The particular emphasis on the design of the roads in accordance with the landscape as a strategy to make the scenic beauties of the city visible particularly reveals the considerations Jansen had in relation to Stadtlandschaft.

The second consideration, especially in relation to the imprints of the Garden City movement and the promotion of Stadtlandschaft as an ideal 
45. As Cuda $(1939,46)$ notes, Jansen's arrangement of the green axes and roads in a perpendicular direction to the sea actually stems from the intention to provide inner parts of the city fresh breeze from the sea. for urban planning, should be devoted to the extent at which the plan tried to create green axes that could cut across the city, but particularly the residential districts. Again, what is evident from the plan and other related documents is that it did not only create green axes, but also systematized them into a coherent whole in terms of a hierarchy and order that facilitates the circulation of pedestrians in the city with an intimate experience of urban landscape (Figure 6). In the plan, Jansen proposed six green axes that crossed the city from north to south running until the seashore where they merged with the promenade (45). Concurrent to this was the pedestrian axes that also went along with the green axes. Jansen tried to segregate roads according to the needs of vehicular traffic and pedestrian circulation. This also involved the allocation of some of the existing roads originally designed and built for vehicular traffic to pedestrian circulation. He tried to make the cortege area, passenger stations, sports areas and parks-gardens accessible especially for women and children who could reach them along the pedestrian axes equipped with trees providing shade.

What were complementary to these in the plan were the special parks and sports complexes. For Jansen, a modern city that considers the health of its residents should have a good sports complex which includes a stadium, tennis courts, a gymnastics hall, a public bath, a swimming pool, a meadow for sunbathing, a restaurant located in a good garden and grand-stands. Within this context, two sports complexes were proposed in the plan; one in the residential district designed for the high and middle-income groups, and the other in the residential district designed for the low-income group (Figure 3,5$)$. Existence of two sports complexes in the plan, one for high and middle income groups and the other one for low income group, is completely in line with the social reformist nature of Garden City movement that was based on the provision of each resident with equal access to the public services.

Another complex in the plan that involved sports facilities such as tennis courts was the Kurhaus complex located at the western end of the promenade just beside the brook and the sea. Kurhaus included not only tennis courts, but also rose gardens and a hotel. Actually, all the hotels in the plan were placed along the promenade. Jansen placed a special emphasis on the promenade which lay between the port and the military barracks that would be relocated outside the city in order to make the establishment of the Kurhaus possible. Jansen noted that the resort opportunities of Mersin, the sea and mild climate, were not being properly used. For this reason, in the plan he proposed a promenade along the seashore which would meet the needs of the residents. At the opposite side of the brook where the promenade reaches the Kurhaus, Jansen proposed a beach equipped with facilities that would attract people, both local and from outside the region. As it was also emphasized by Cuda $(1939,46)$, there was a clear intention in the plan in order to transform Mersin into an attractive sea resort. Nevertheless, Cuda $(1939,47)$ notes that this was not an easy task because of the harbour facilities in the city. In this respect, it is important to note that in the plan industrial district and beach were located far from each other at the opposite ends of the city along the coast from the east to the west. CBD and the residential areas divided by large green axes lay in between them.

Compared with especially his plan prepared for Ankara, what is remarkable in all these decisions and proposals introduced in Jansen's Mersin plan is the serious consideration devoted to the economic aspects. 
Although this can be considered as a reflection of the Garden City movement that assigns an extraordinary importance to the feasibility of the planning schemes, there is no doubt that the Great Depression of the 1930s was also instrumental in these decisions. Owing to its designation as a capital city Ankara has always received considerable amount of financial assistance from the central government. However, this does not mean that other cities in the country were ignored. Furthermore, as noted above, the invitation of Jansen to Çukurova region was the result of a local initiative despite some speculations implying that Jansen's involvement in Çukurova was due to the importance assigned to the region by the central government owing to its fertile agricultural lands.

Considering the lack of financial resources required to implement the urban development plans prepared for Mersin and other cities in Çukurova region, in taking his planning decisions Jansen made an effort to economize on the cost of implementation of the plan. Indeed, in both the report explaining the plan and the interviews held with him, Jansen always put emphasis on the financial aspects of the decisions taken in the plan. For example, after seeing the poor condition of the beach, he explained how it could be easily rehabilitated without increasing the burden on the municipality. Although this orientation (to be more economic and rational) can be evaluated as a positive side of the plan, in fact, it seems to create some problems, too. For example, in the plan prepared by Jansen for Mersin, streets were very narrow (46). Indeed, Jansen accentuated the financial aspects of the plan so much that roads in the plan seem to be unnecessarily narrow. Jansen recommended that the boulevards and streets which were numerous in Mersin and increased the burden of the plan should be simplified into a coherent and systemic whole involving a certain hierarchy.

In connection with Jansen's financial considerations in his plans, it is important to note that during the early Republican period Turkish cities became an active arena for German and French planners to lay out and discuss their style of planning and views (Tekeli, 2005). The monumental and particularly diagonal 'boulevards' largely inherited from Haussmann's planning operation in Paris could not be found in the urban development plans prepared by German planners (Tekeli, 1980; Hein, 2002, 254). Indeed, in contrast with Jansen's urban development plan prepared for Ankara in line with Camillo Sitte's aesthetic principles sensitive to the existing traditional fabric and the Garden City movement, French planner Jaussely proposed an entirely new layout neglecting the picturesque old town (Tekeli, 1980; Hastaoglou-Martinidis, 2011, 166-7). In an interview given by Jansen to Ziya Toroğlu (a journalist from Yeni Mersin), in order to defend his thesis, Jansen also gave an example from Adana for which both French planners and he prepared an urban development plan (47). He showed that in the plan prepared by the French planners, houses were adjacent to each other and the amount of area covered by the roads was 160,000 square meters. He claimed that employing his own style of planning, in the same district planned by the French planners, the area covered by the roads could be reduced to 40,000 square meters (Figure 7). He added that this could be realized by allocating houses into separate lots having small

46. Develi $(2001,124)$ notes that these streets were so narrow that two cars could hardly go along side by side.

47. 'Yansen Tezini Müdafaa Ediyor', Yeni Mersin, 7 October 1936, 1-2. gardens.

In relation to both the economic aspects of the plan and the effects of the Garden City movement, the third important consideration should be devoted to the extent to which dwelling units in the plan are differentiated 
Figure 7. A small area planned by both Jansen and French Planners in Adana. (Tekeli, 1980). The plan on the left drawn by French Planners; the one on the right by Jansen himself.
Figure 8. Reflection of self-sufficiency favored the Garden City movement and Stadtlandschaft in workers's district proposed by Jansen in his Mersin Plan (For cultivation of vegetables extra gardens are placed around workers' dwellings, in order to decrease the burden of workers in relation to the expenses made for the purchase of food).
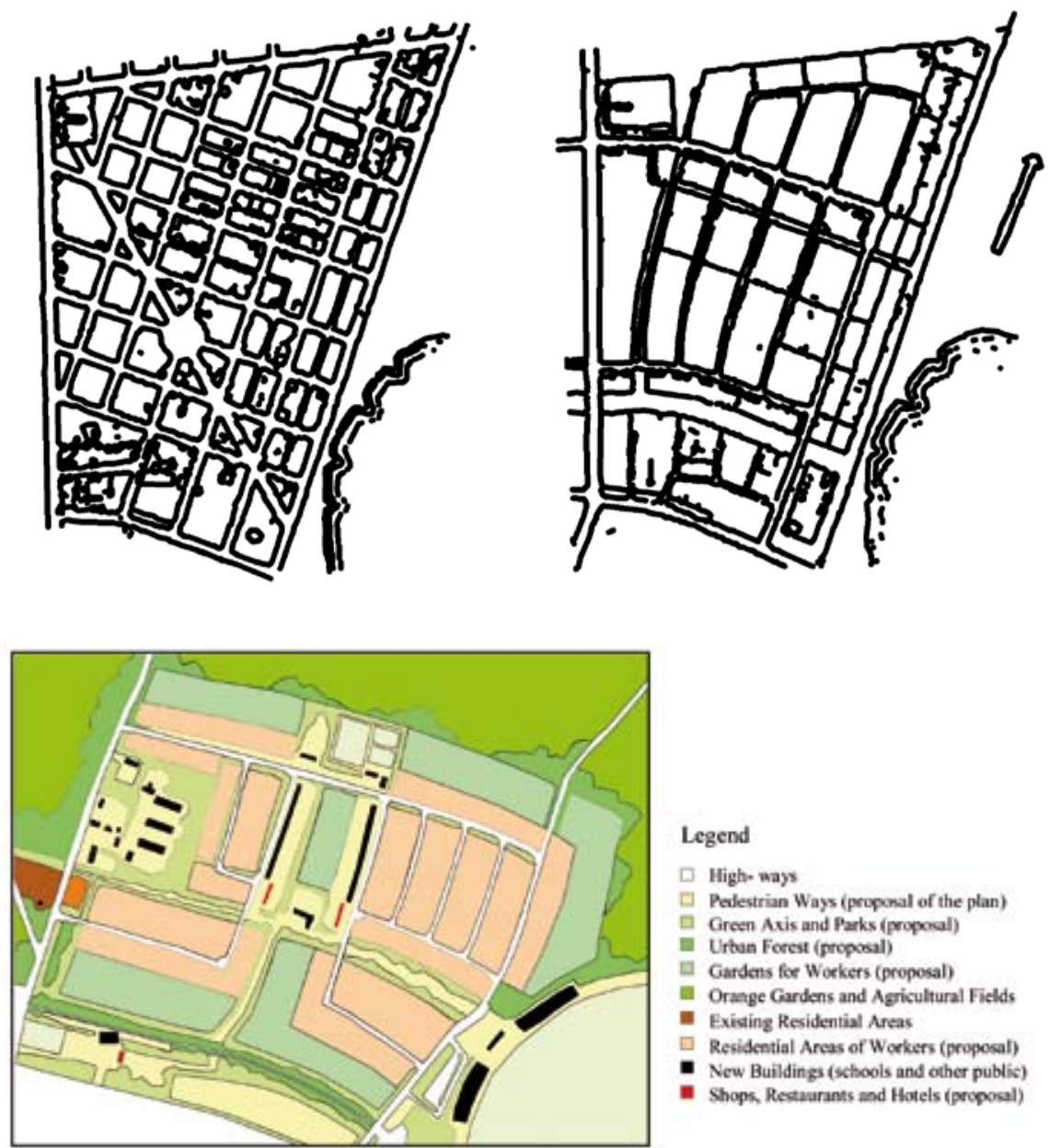

Legend

High- ways

1. Pedestrian Ways (proponal of the plan)

areen Axis and Parks (proporal)

Urtan Ferest (proposal)

2. Gardens foe Workers (proposal)

arange Gardens and Agricultural Fields

- Exising Residential Areas

1- Residential Areas of Workers (proposal)

- New Buildings (schools and other public)

n' Shops, Restaurants and Hotels (proposal)
48. As the Uray and Silifke streets were narrow they could not be converted into main streets. Consequently, Jansen proposed a transit road that went along the fringes of the existing city and separated the worker dwellings from the main city. according to the income groups and associated with the gardens providing the inhabitans with some sort of self sufficiency. Indeed, as geographer and planning historian Ronald Phillips (1977) argues, Howard's town-country magnet is based on not only a physical schema, but also community model requiring the public ownership of the land subject to planning. According to Jansen, houses having gardens were healthier than those adjacent to each other because of the protection from exhaust produced by the cars. What is evident from the plan is that a great deal of consideration in the plan was devoted to both the creation of separate residential districts for rich and poor inhabitants of the city, and the creation of dwelling units having gardens. Jansen insisted that not only rich but also poor residents of the city should be able to buy houses. In the plan, worker's dwellings were located in a separate district just near the industrial area (Figure 8). They were located in the gardens which were collectively used by all. Some other gardens designed for the cultivation of vegetables were also placed around the workers' dwellings in order to decrease the burden of workers in relation to the expenses made for the purchase of foodstuffs. Another concern in the creation of a separate residential district for workers was to relocate the poor residents living in ruined houses in the old city to the respective area. It should be noted that in the plan the areas lying along the transit roads that might cause noise and dust were not used for residential purposes (48). Rather, they were afforested. 
49. Cuda $(1939,45-6)$ notes that in the plan, extension of the railway to the west in the direction of Selefke (Seleucia) was primarily aimed at shifting the station more to the city center, so that it could be easily accessible from both directions of the city. The purpose of the bypass road was to prevent the traffic congestion in the city center. This way, camel caravans and vehicles coming from Selefke would not any more cross the old part of town in the longitudinal direction.
In accordance with Howard's model which incorporates technology into the garden city, Jansen was particularly sensitive to the employment of modern modes of transportation. Within this context, he proposed the extension of the railway towards the west, the construction of a small airport to the east of the city, and also a bypass road (49). Last, but not least, Jansen proposed a new administrative center. As the close environs of the governor's office were increasingly invaded by commercial activities, a new center for administration was necessary in Mersin. The new administrative center involved the most important public buildings and hallmarks of the city. Atatürk Park was the defining element of the new administrative center. In the plan, public house, library, administrative offices and the mansion of governor were placed there. In this center, there was also a dancing pavilion and a pub.

Overall, what is evident from the analysis of the urban plan development prepared by Jansen for Mersin is that it reflects the typical characteristics of not only the principles of Camillo Sitte and Garden City movement, but also Stadtlandschaft. Although the general framework employed by Jansen in the urban development plan for Mersin overlaps with the ones used by him for the other cities in both Europe and Turkey, compared with the Western experience the preparation of urban development plans for Turkish cities is actually late. Nevertheless, emerging from the ashes of an empire the young Turkish Republic mobilized all the sources available in the country for the creation of a modern nation and state. Unfortunately, in the subsequent years, majority of the urban development plans, even the one prepared for the capital city, could not be successfully implemented due to a series of factors including especially the ones associated with rentseeking activities.

\section{CONCLUDING REMARKS}

This paper contextualizes the early planning efforts made for Mersin by focusing on the spatial imprints of modernity on Mersin in terms of both the socio-cultural and institutional contexts in which the city developed as a port, and in terms of the planning ideas favored in the plan. As it developed during the second half of the 19th century, throughout which strict planning regulations were introduced to Ottoman cities, Mersin did not have an organic urban pattern observed in the older parts of other cities established long before the 19th century when the Tanzimat was declared in the Ottoman Empire. Thus, the emergence of a predominant grid pattern in the city was inevitable. However, parallel to the planning style that was dominant in the early years of the Republic, this characteristic of the city was challenged by Jansen who prepared the first urban development plan for the city in 1938. This plan reflected all the characteristics of the way through which the leaders and intellectuals of the Republic chose to modernize the cities in Turkey: it involved a symbiosis of old and new, of urban and rural through the strong considerations devoted to the economic aspects of the plan.

Indeed, as it was also the case for Ankara, Adana and other cities planned by him, Jansen preserved the historical fabric as long as possible by reorganizing the street system and providing green areas. For this purpose, in line with Camillo Sitte, historical buildings were not only identified and preserved, but also designated as important nodes of pedestrian circulation through the green axes. Again in line with the Garden City movement, Jansen tried not only to restrict the growth of Mersin as a port city, but also 
to create self-supporting communities living in residential areas equipped with the gardens providing the inhabitans with some sort of self sufficiency and separated from each other by large green axes. Jansen's search for Stadtlandschaft is also visible in his Mersin plan in terms of not only an active effort made for the creation of a low density urban environment characterized by a harmony between built environment and nature, but also integration of the historical core, (proposed) residential areas, industrial zone and landscape "into a unified system structured by the transportation networks". Combined with the motives of leaders and intellectuals of the Republic all these characteristics reflected in the urban development plan prepared by Jansen for Mersin, actually reveal the will to modernize the city in a different and somewhat original way. In the years following the preparation of the plan, the needs of the contemporary world might have created some problems in relation to development of the city, which necessitates a detailed and serious survey of the implementation of the plan, as a future research.

As an alternative to the accounts prioritizing İstanbul and Ankara as the main scenes for the first urban planning attempts, respectively, in the Ottoman Empire and the Republic of Turkey, in this paper the urban planning in Turkey has been reexamined as a tool of modernization through the illustrative case of Mersin that, in many respects, functions as a lens for the Turkish (port) cities which are not well-known. Beyond this, more implicit in character in this study is a call to understand the nature and objectives of planning today through the historical analysis of the evolution of planning efforts. As Cherry $(1969,55)$ notes, urban planning as an "attempt to extend the potential benefits of the Industrial Revolution to members of all classes" is a critical factor in the creation of democratic society both in concept and practice. Nevertheless, the truncated image of urban planning as "an exercise in the physical control of land or forms of development" still dominates the implementations in the respective field. Yet, excursions into the history of planning provide us with, as Cherry (1969, 56) emphasize, "the greatest significance for the understanding of its nature and objectives today". In this respect, future studies may reveal particular stories for the other cities planned during the 1930s and 1940s in Turkey.

What is further evident from the paper is that modernization efforts made for Mersin are completely in line with the basic features of a seaport city characterized as open to the international diffusion of ideas and cultures. In this respect, invitation of Jansen to Çukurova to plan Mersin and other cities in the region was not only an extention of the will of the republican cadre to modernize cities in the country, but also definetely a reflection of the energetic spirit of the local administrators in touch with different cultures to shape the city according to the principles and methods of modern urban planning. Based on the news published in local newspapers, this energetic spirit is successfully unveiled for the particular case of Mersin in this study, which, combined with other explanatory and exploratory materials compiled from the respective source reveals that local newspapers are very valuable not only for urban history in general, but also planning history in particular. Employment of the respective sources for the elaboration of the planning efforts made for other cities in Turkey may help us construct the categories in a more proper way, instead of accepting what is already proposed or implied in the literature.

Further, as Ward (2005) points out, the relationship between the planners and the city planned by them is a mutual one implying that they both 
affected and were affected by the planning culture available for the respective city. As it is already argued by Akcan (2009: 228-34, 373-98) for the particular cases of Ernst Egli and Bruno Taut who worked in Turkey during 1930s, the experiences of foreign architects and planners in Turkey had affected their conception of architecture and planning during their sub-sequent careers in other countries. In the case of Jansen, such an investigation requires a detailed examination of the plans made by him for other cities after his involvement in the preparation of urban development plans in Turkey, and might be the topic of another article.

\section{ACKNOWLEDGMENTS}

We would like to thank Prof.Dr. Eyüp Özveren for he encouraged us in 2002, to delve into the records of urban and planning history through the pages of local newspapers. We would also like to thank Prof.Dr. Sevgi Aktüre for her constructive comments and suggestions on an earlier draft of this paper.

\section{BIBLIOGRAPHY}

AÇIKGÖZ, U.F. (2008) A Case in French Colonial Politics of Architecture and Urbanism: Antioch and Alexandretta During the Mandate, unpublished Master thesis, Graduate School of Social Sciences, Middle East Technical University, Department of History of Architecture, Ankara.

AKCAN, E. (2005) Modernity in translation: Early twentieth-century German-Turkish exchanges in land settlement and residential culture, unpublished Ph.D. Dissertation, Columbia University, New York.

AKCAN, E. (2009) Çeviride Modern Olan: Şehir ve Konutta Türk-Alman İlişkileri, Cogito, Yapı Kredi Yayınları, İstanbul.

AKIN, E. (2007) Kentsel Gelişme ve Kentsel Rantlar: Ankara Örneği, unpublished Ph.D. Dissertation, Department of Urban and Environmental Sciences, Graduate School of Social Sciences, Ankara University, Ankara.

AKSOYLU, S. (2003) A Critical Outlook to the Planning Practices of Turkey from the Beginning of the Republican Period, paper presented at the Second Annual Hawaii International Conference on Social Sciences, Honolulu, Hawai, USA.

AKTÜRE, S. (1978) 19. Yüzyıl Sonunda Anadolu Kenti, ODTÜ Mimarlık Fakültesi Baskı Atölyesi, Ankara.

AKTÜRE, S. (1985) Osmanlı Devletinde Taşra Kentlerindeki Değişimler, in Tanzimat'tan Cumhuriyet'e Türkiye Ansiklopedisi (4) 891-902.

AYATAÇ, H. (2007) The International Diffusion of Planning Ideas: The Case of Istanbul, Turkey, Journal of Planning History (6) 114-37.

AYKIN, Z. (2007) Mersin'in Dizili (Kronolojik) Tarihi, Mali Ufuklar (39) 118.

BAĞBANCI, M.B., KÖPRÜLÜ BAĞBANCI, Ö. (2010) Urban Reforms of Tanzimat: Early Urbanization and Transportation Practices in the Formation Process of Turkish Reconstruction System (1839-1908) in Bursa, the First Capital City of Ottoman Empire, World Academy of Science, Engineering and Technology (66) 1121-6. 
BATCHELOR, P. (1969) The Origin of the Garden City Concept of Urban Form, Journal of the Society of Architectural Historians (28) 184-200.

BEYHAN, B. (2009) Mersin Hotels: A Chronological and Spatial Inquiry, paper presented at the colloquium Mersin the Mediterranean World, and the Twentieth Century - Intersecting Trajectories, Başak Ofset, Mersin; 191-236.

BEYHAN, B., BELGE, B., ZORLU, F. (2010) Özgür ve Açık Kaynak Kodlu Masaüstü CBS Yazılımları Üzerine: Karşılaştırmalı ve Sistemli bir Değerlendirme (Free and Open Source Desktop GIS Software Programs: A Comparative and Systematic Evaluation), Harita Dergisi, (143) 45-61.

BEYHAN, B., UĞUZ, S. (2002) Modernity's Imprints on Mersin: A Reinterpretation, paper presented at the colloquium Mersin, the Mediterranean, and Modernity: Heritage of the Long Nineteenth Century (19. Yüzyılda Mersin ve Akdeniz Dünyası), Selim Ofset, Mersin; 86-101.

BİLSEL, C. (1996) Ideology and Urbanism During The Early Republican Period: Two Master Plans for İzmir and Scenarios of Modernization, METU Journal of the Faculty of Architecture (16) 13-30.

BİLSEL, C. (2009) İzmir'de Cumhuriyet Dönemi Planlamas1 (1923-1965): 20. Yüzyıl Kentsel Mirası, Ege Mimarlik (71) 12-7.

BOZKURT, U., (2004) The Morphological Characteristics of the Block Structure in Central Areas, unpublished Master Thesis, İzmir Institute of Technology, City and Regional Planning, Major: Urban Design.

BUDER, S. (1969) Ebenezer Howard: The Genesis of a Town Planning Movement, Journal of the American Planning Association (35) 390-98.

BURT, R.S. (1992) Structural Holes: The Social Structure of Competition, Harvard University Press, Cambridge.

ÇELIK, Z. (1993) The Remaking of İstanbul: Portrait of an Ottoman City in the Nineteenth Century, University of California Pres, Berkeley.

CENGİZKAN, A. (2002) Ankara 1924-25 Lörcher Planı: Bir Başkenti Tasarlamak ve Sonras1, Arredamento Mimarlik, (10) 116-32.

CENGIZKAN, A. (2004) Ankara'nın Ilk Planı: 1924-25 Lörcher Planı, Ankara Enstitüsü Vakfı, Arkadaş Yayıncılık Ltd., Ankara.

CENGIZZKAN, A. (2010) The production of a mise en scène for a nation and its subjects: Clemens Holzmeister et al. in the Ministries Quarter for Ankara, Turkey, The Journal of Architecture (15) 731-70.

CHERRY, G.E. (1969) Influences on the Development of Town Planning in Britain, Journal of Contemporary History (4) 43-58.

CONLEY, T.D. (2010) Belgrade, Capital Cities in the Aftermath of Empires: Planning in Central and Southeastern Europe, eds. E.G. Makaš, T.D. Conley, Routledge, London; 45-60.

CONLEY, T.D., MAKAŠ, E.G. (2010) Shaping Central and Southeastern European Capital Cities in the Age of Nationalism, Capital Cities in the Aftermath of Empires: Planning in Central and Southeastern Europe, eds. E.G. Makaš, T.D. Conley, Routledge, London; 1-28.

CRAWFORD, A.W. (1910) City Planning and Philadelphia Parks, Annals of the American Academy of Political and Social Science (35) 71-80. 
CUDA, A. (1939) Stadtaufbau in der Türkei, Die Welt des Islams (21) 1-84.

DEVELİ, Ş. (2000) Mersin'de Modern Şehircilikde İlk Adım Yansen Planı (1935-1939), İçel Sanat Kulübü Bülteni (92) 8-9.

DEVELİ, Ş. (2001) Dünden Bugüne Mersin 1836-1990, MTSO Yayınları, Gözde Ofset, Mersin.

DUEMPELMANN, S. (2009) Creating order with nature: Transatlantic transfer of ideas in park system planning in twentieth-century Washington D.C., Chicago, Berlin and Rome, Planning Perspectives (24) 143-73.

FRIES, F. (1994) Les Plans d'Alep et de Damas, un banc d'essai pour l'urbanisme des frères Danger (1931-1937), Figures de l'Orientalisme en Architecture, a special issue of Revue du Monde Musulman et de la Méditerranée, eds. C. Bruant, S. Leprun, M. Volait (73-74) 311-26.

GRANOVETTER, M. (1973) The Strength of Weak Ties, American Journal of Sociology (78) 1360-80.

GÜL, M. (2009) The Emergence of Modern İstanbul: Transformation and Modernisation of a City, Tauris Academic Studies, London and New York.

GÜL, M., LAMB, R. (2004) Mapping, Regularizing, and Modernizing Ottoman İstanbul: Aspects of the Genesis of the 1839 Development Policy, Urban History (31) 420-36.

HALL, T. (1991) Urban Planning in Sweden, Planning and Urban Growth in Nordic Countries, ed. T. Hall, Chapman and Hall, London; 190-280.

HALL, T., ed. (1991) Planning and Urban Growth in Nordic Countries, Chapman and Hall, London.

HARB, M. (2003) La Dahiye de Beyrouth: parcours d'une stigmatisation urbaine, consolidation d'un territoire politique, Genèses (51) 70-91.

HASTAOGLOU-MARTINIDIS, V. (2011) Urban aesthetics and national identity: The refashioning of Eastern Mediterranean cities between 1900 and 1940, Planning Perspectives (26) 153-82.

HEIN C., eds. (2011) Port Cities: Dynamic Landscapes and Global Networks, Routledge, London.

HEIN, C. (2002) Maurice Rotival: French planning on a world-scale (Part I), Planning Perspectives (17) 247-265.

HEIN, C. (2006) In search of icons for a United Europe, City (10) 71-89.

HEIN, C. (2011a) Port Cityscapes: A networked analysis of the built environment, Port Cities: Dynamic Landscapes and Global Networks, ed. C. Hein, Routledge, London; 1-23.

HEIN, C. (2011b) Hamburg's Port Cityscape: Large-scale urban transformation and the exchange of planning ideas, Port Cities: Dynamic Landscapes and Global Networks, ed. C. Hein, Routledge, London; 177-97.

HOWARD, E. (1902) Garden Cities of To-Morrow (Being the Second Edition of "To-Morrow: A Peaceful Path to Real Reform"), Swan Sonnenschein \& Co., Ltd. Paternoster Square, London. 
KAÇAR, D. (2010) Ankara, a Small Town, Transformed to a Nation's Capital, Journal of Planning History (9) 43-65.

KELEŞ, R., DURU, B. (2008) Ankara'nın Ülke Kentleşmesindeki Etkilerine Tarihsel Bir Bakış, Mülkiye (XXXII) 27-44.

KELEŞ, R., PAYNE, G.K. (1984) Turkey, Planning and Urban Growth in Southern Europe, ed. M. Wynn, Mansell, London; 165-97.

KENDALL, E. (2002) Between Politics and Literature: Journals in Alexandria and Istanbul at the End of the Nineteenth Century, Modernity and Culture: From the Mediterranean to the Indian Ocean, eds. L.T. Fawaz, C.A. Bayly, R. Ilbert, Columbia Unıversity Pres, Newyork; 330-43.

KESKİNOK, H.Ç. (2010) Urban Planning Experience of Turkey in the 1930s, METU Journal of the Faculty of Architecture (27), 173-88.

KEZER, Z. (1998) Contesting Urban Space in Early Republican Ankara, Journal of Architectural Education (52) 11-9.

KEZER, Z. (2010) Ankara, Capital Cities in the Aftermath of Empires: Planning in Central and Southeastern Europe, eds. E.G. Makaš, T.D. Conley, Routledge, London; 124-40.

KONURSAY, S.Y. (2004) Land Readjustment Process in Urban Design: Project Management Approach, unpublished Master thesis, Department of City and Regional Planning, İzmir Institute of Technology, İzmir.

LARSSON, B., THOMASSEN, O. (1991) Urban Planning in Denmark, Planning and Urban Growth in Nordic Countries, ed. T. Hall, Chapman and Hall, London; 7- 67.

LORANGE, E., MYHRE, J.E. (1991) Urban Planning in Norway, Planning and Urban Growth in Nordic Countries, ed. T. Hall, Chapman and Hall, London; 133- 189.

MANTZIARAS, P. (2002) Rudolf Schwarz and the Concept of "CityLandscape", Arquitectura, ciudad e ideología antiurbana, Actas Del Congreso Internacional, 15-36.

MANTZIARAS, P. (2003) Rudolf Schwarz and the concept of Stadtlandschaft, Planning Perspectives, (18) 147-76.

McPHERSON, K. (2002) Port Cities as Nodal Points of Change: The Indian Ocean, 1890s-1920s, Modernity and Culture: From the Mediterranean to the Indian Ocean, eds. L.T. Fawaz, C.A. Bayly, R. Ilbert, Columbia University Press, Newyork; 75-95.

MERT, H. (1999) 19. Yüzyılın sonlarında Karçınzade Süleyman Şükrü'nün Gözüyle Çukurova, in the proceedings of III. Uluslararası Çukurova Halk Kültürü Bilgi Şöleni, Adana; 497-505.

MUMCU UÇAR, Ö., ÖZSOY, A. (2006) Sınır kavramına mekânsal bir yaklaşım: Bahçelievler örneği, itü dergisi / a mimarlık, planlama, tasarım (5) $11-24$.

NEDOVIĆ-BUDIĆ, Z., CAVRIĆ, B. (2006) Waves of planning: a framework for studying the evolution of planning systems and empirical insights from Serbia and Montenegro, Planning Perspectives (21) 393425 . 
NEUMAN, M., GAVINHA, J. (2005) The planning dialectic of continuity and change: The evolution of metropolitan planning in Madrid, European Planning Studies (13) 985-1012.

O'FLANAGAN, P. (2008) Port Cities of Atlantic Iberia, c. 1500-1900, Ashgate Publishing Limited, Aldershot, Hampshire.

OLMSTED, F.L. (1914) The Town-Planning Movement in America, Annals of the American Academy of Political and Social Science (51) 172-81.

ÖZCAN, K. (2006) Tanzimat'ın Kent Reformları: Türk İmar Sisteminin Kuruluş Sürecinde Erken Planlama Deneyimleri (1839-1908), Osmanlı Bilimi Araştırmaları (Studies in Ottoman Science) (7) 149-80.

ÖZCAN, Ü. (2000) İmar Mevzuatının ve Kentsel Toprak Mülkiyetinin İrdelenmesi, TODAİE, Yerel Yönetimler Araştırma ve Eğitim Merkezi Yerel Temsil Araştırması (Yeryön/İmar), Ankara.

ÖZSOY, T., ÖRNEKTEKİN, S. (2008) Kuzeydoğu Akdeniz'de Kız1l Yağmurlar, Ekoloji (18) 20-31.

PEERASON, M.N. (1998) Port Cities and Intruders: The Swahili Coast, India, and Portugal in the Early Modern Era, Johns Hopkins University Press, Baltimore.

PHILLIPS, R.A. (1977) The Garden City movement: Its Origins and Influence on Early Modern Town Planning, unpublished Master Thesis, Department of Geography, Simon Fraser University.

PINON, P. (2006) Les Anciens Plans Cadastraux d'İstanbul, Città e Storia (I) 537-52.

REUTHER, H. (1974) Hermann Jansen, in Neue Deutsche Biographie (10) Duncker and Humblot, Berlin.

SABAN ÖKESLİ, D. (2009) Hermann Jansen's Planning Principles and His Urban Legacy in Adana, METU Journal of Faculty of Architecture (26) 45-67.

SABAN ÖKESLİ, D. (2010) Hermann Jansen and His Urban Legacy in Southern Turkey, 14th IPHS Conference - Urban Transformation: Controversies, Contrasts and Challenges, İstanbul, Turkey.

ŞAHIN, S.Z. (2007) The Politics of Urban Planning in Ankara Between 1985 and 2005, unpublished Ph.D. Dissertation, Graduate School of Social Sciences, Middle East Technical University.

SCHENK, T.A., BROMLEY, R. (2003) Mass-Producing Traditional Small Cities: Gottfried Feder's Vision for a Greater Nazi Germany, Journal of Planning History (2) 107-39.

SCHUBERT, D. (2004) Theodor Fritsch and the German (völkische) version of the Garden City: The Garden City invented two years before Ebenezer Howard, Planning Perspectives (19) 3-35.

SITTE, C. (2006) City Planning According to Artistic Principles, Dover Publications, Mineola, New York. Translated from the German by George R. Collins and Christiane Crasemann Collins. Original German version titled Der Städtebau nach seinen künstlerischen Grundsätzen published in 1889 by Verlag von Carl Graeser, Vienna.

SOFFER, A., STERN, S. (1986) The Port City: A Sub-group of the MiddleEastern City Model, Ekistics (53) 102-10. 
SOHN, E. (2003) Hans Bernhard Reichow and the concept of Stadtlandschaft in German planning, Planning Perspectives (18) 11946.

SOHN, E. (2007) Organicist Concepts of City Landscape in German Planning after the Second World War, Landscape Research (32) 499523.

SONNE, W. (2003) "The Entire City Shall Be Planned as a Work of Art". Städtebau als Kunst im frühen modernen Urbanismus 1890-1920, Zeitschrift für Kunstgeschichte (66) 207-36.

SONNE, W. (2004) Specific intentions-general realities: on the relation between urban forms and political aspirations in Berlin during the twentieth century, Planning Perspectives (19) 283-310.

STEINIGER, S., BOCHER, E. (2009) An overview on current free and open source desktop GIS developments, International Journal of Geographical Information Science (23) 1345-70.

SUNDMAN, M. (1991) Urban Planning in Finland after 1850, Planning and Urban Growth in Nordic Countries, ed. T. Hall, Chapman and Hall, London; 68-132.

SZRETER, S., MOONEY, G. (1998) Urbanization, mortality, and the standard of living debate: new estimates of the expectation of life at birth in nineteenth-century British cities, Economic History Review (51) 84-112.

TANKUT, G. (1981) Jansen Planı: Uygulama Sorunları ve Cumhuriyet Bürokrasisinin Kent Planına Yaklaşımı, Tarih İçinde Ankara,

TANKUT, G. (1993) Bir Başkentin İmarı, Anahtar Kitaplar, İstanbul.

TEKELİ, İ. (1980) Türkiye'de Kent Planlamasının Tarihsel Kökenleri, Türkiye'de İmar Planlaması, ed. T. Gök, ODTÜ Mimarlık Fakültesi Baskı İşliği, Ankara; 8-112.

TEKELİ, İ. (1985) Tanzimattan Cumhuriyete Kentsel Dönüşüm, in Tanzimat'tan Cumhuriyet'e Türkiye Ansiklopedisi (4) 878-90.

TEKELİ, İ. (2005) Türkiye'de Kent Planlaması Düşüncesinin Gelişimi, XXII. Yunus Aran Conference.

TILLYARD, F. (1913) English Town Development in the Nineteenth Century, The Economic Journal (23) 547-60.

Town Planning Review (1910) 'Chronicle of Passing Events: “Illustrated"', (1).

TÜRKOĞLU ÖNGE, S. (2007) Spatial Representation of Power: Making the Urban Space of Ankara in the Early Republican Period, Power and Culture: Identity, Ideology, Representation, eds. J. Osmond, A. Cimdina, Edizioni Plus, Pisa University Press, Pisa; 71-94.

ÜNLÜ, T. (2007) Mersin'in Mekansal Biçimlenme Süreci ve Planlama Deneyimleri, Gazi Üniversitesi Mühendislik Mimarlık Fakültesi Dergisi, (22) 425-36.

ÜNLÜ, T. (2009) Mekansal Planlamanın Kentin Biçimlenmesinde Etkisi: Mersin Örneği, Planlama, (3/4) 27-42. 
ÜNLÜ, T., LEVENT, T. (2005) Mersin'de Kentsel Mekanın Biçimlenmesinde Jansen Planı'nın Etkileri, Tarih İçinde Mersin: Kolokyum II'de sunulan bildiri, Mersin Üniversitesi, Mersin;160-75.

VACHER, H. (2002) Building the modern city: planners and planning expertise at Léon Eyrolles' Ecole Spéciale des Travaux Publics, 18981939, Planning Perspectives (17) 41-59.

WARD, S.V. (2005) A pioneer 'global intelligence corps'? The internationalisation of planning practice, 1890-1939, Town Planning Review (76) 119-141.

WILLCOCKS, R.E. (1911) Town Planning, Journal of the Society of Comparative Legislation, (11) 211-9.

WYNN, M. (1984) Spain, Planning and Urban Growth in Southern Europe, ed. M. Wynn, Mansell, London; 111-63.

YAVUZ, F. (1952) Ankara'nın Imarı ve Şehirciliğimiz, Ankara Üniversitesi Siyasal Bilgiler Fakültesi Yayınları, Ankara.

YAVUZ, F. (1980) Kentsel Topraklar: Ülkemizde ve Başka Ülkelerde, Ankara Üniversitesi Siyasal Bilgiler Fakültesi Yayınları, Ankara.

YAVUZ, F. (1981) Başkent Ankara ve Jansen, ODTÜ Mimarlık Fakültesi Dergisi (7) 25-33.

YERASIMOS, S. (1988) La planification de l'espace en Turquie, Revue du Monde Musulman et de la Méditerranée (50) 109-22.

YERASIMMOS, S. (1999) Tanzimat'ın Kent Reformları Üzerine, Modernleşme Sürecinde Osmanlı Kentleri, ed. P. Dumont, F. Georgeon, trans. Ali Berktay, Tarih Vakfı Yurt Yayınları, İstanbul; 1-18.

Alınd1: 09.09.2011, Son Metin: 27.04.2012

Anahtar Sözcükler: eski kentsel gelișme planları ve düzenlemeler; liman kentleri; planlama fikirlerinin yayılım, Hermann Jansen; Mersin.

\section{TÜRKIYYE'DE BİR MODERNLEŞME ARACI OLARAK PLANLAMA: HERMANN JANSEN'İN MERSİN PLANI ÖRNEĞİ}

Yirminci yüzyılın ilk yıllarında yapılan kentsel gelişme planları ve yasal düzenlemeler, kentlerin modernleşmesi doğrultusunda harcanan çabaların birikimi olarak, planlamanın doğası ve hedeflerinin günümüzde anlaşılması ve şehirlerin tarihsel olarak irdelenmesi için özel ve asal bir ilgi alanı oluşturmaktadır. Ancak Ankara, İstanbul, İzmir, Adana ve Bursa gibi büyük şehirler dışında Türkiye'deki diğer şehirlerin çoğu bu açıdan irdelenmemiştir. Ayrıca ne yazık ki, hem büyük hem de küçük kentler için yapılan çalışmalarda söz konusu planların hazırlandığı dönemin yerel sosyo-kültürel ve kurumsal ortamı yeterince açımlanmamaktadır. Bu makale, Mersin için yapılan planlama çalışmalarının bağlamlararası ve bağlamiçi niteliklerini aydınlatarak, kısmen bu boşluğu doldurmaktadır. Çalışmanın temel amacı, hem 20. yüzyıl başında Türkiye'de orta-ölçekli bir liman kentinin planlanması için harcanan çabaların bağlamsal çerçevesinin çizilmesi, hem de söz konusu dönem boyunca Türkiye'de yaşanan kentsel dönüşümün çok fazla bilinmeyen Türk (liman) kentlerindeki yansıması açısından, bir büyüteç görevi gören Mersin üzerinden anlaşılmasıdır. $\mathrm{Bu}$ tarihsel irdelemeden ortaya çıkan en önemli sonuç, Mersin'in planlama serüveninin Türkiye Cumhuriyeti'nin kurucu liderlerinin ve aydınlarının Cumhuriyetin ilk yıllarında ülkedeki kentlerin modernleştirilmesi sürecinde benimsediği tüm nitelikleri yansıttı̆̆ gerçeğidir. 
BURAK BEYHAN, B.CP., M.RP., Ph.D.

Received his degrees in the Department of City and Regional Planning at METU, in Ankara; currently assistant professor at Mersin University. Main research interests are in regional planning and economic development, innovation and geographic information systems, urban and planning history. burakbeyhan@yahoo.com

SELÇUK UĞUZ, B.Sc.

Received his bachelor degree in the Department of Economics at METU, in Ankara; currently working for an international construction firm in İstanbul. 